\title{
MARKSIZM ve HUKUK
}

\author{
Dr. Onur Karahanoğulları \\ Ankara Üniversitesi \\ Siyasal Bilgiler Fakültesi
}

\section{Ōzet}

Marx, geliştirdiği araşturma ve inceleme yöntemini bütünsel biçimde sadece, tüm diğer ilişki biçimlerinin temeli olarak, üretim ilişkilerinin çözümlenmesinde kullanmuştır. Bununla birlikte, hukuku çözümleme niyeti her zaman için Marx'ın tasarıları arasında yer almıştur. Marx ve Engels'in hukuka ilişkin, değişik konular bağlamında yaptıkları çok önemli saptamaları bulunmaktadır. Marksizm ve hukuk dendiğinde yaplabilecek temel saptama, dünyanın hukukçu bakış açısıyla açıklanı anlamlandurabileceğinin reddedilmesidir. Ikinci temel tez ise, hukukun kaynağının salt iradede aranmaması gerektiğidir. Marx, dünyanın açıklanmasında hukukun temel araç olarak kullanılmasının yanlışlığını saptadıktan sonra, burada derinleşmemiş ve hukuk üzerinde daha fazla durmadan ilerlemiştir. Çalışmanun ilk bölümünde, hukuk eğitiminin ve hukuk çalışmalarının Marx'ın entelektüel oluşumundaki yeri değerlendirilecektir. Ikinci bölümde Marksizmin hukuk konusundaki temel tezi aktarıldıktan sonra, hukukun kaynağına, incelenme yöntemine, hukukun tarihselliğine, hukukun geleceğine ve siyasal faaliyettcki işlevine ilişkin tezler ele alınacaktır. Calışma sadece Marx ve Engels'in yazılarıyla sınırlanmıştır.

\section{Marxism and Law}

\section{Abstract}

Marx uses the total manner of his research and study method only in the analysis of the relations of production as the basis of all the other relation types. However, the intention to analyse law always finds a place among his projects. Marx and Engels have very important determinations about law in the context of different subjects. When we say Marxism and law, the main determination is the rejection of the understanding and explanation of the world from the lawyer's point of view. Except this, the second thesis of Marxism about law is that the source of law cannot be found in pure volition. After determining the mistake of using law mainly in the explanation of the world, he does not deepen in this subject and he moves ahead. In the first part of this study the place of the law studies in the formation of the intellectual development of Marx will be evaluated. After determining main thesis of Marxism about law, basic thesis on the source of law, the method of studying law, the historical nature of law, the future of law and the role of law in political activities will be examined. The scope of this study is limited with the works of Marx and Engels. 


\section{Marksizm ve Hukuk}

\section{Gíiş̧}

Marksizm toplumsal ilişkilerin, bizzat bu ilişkilerin yaratıcısı ve aktörü olan insan tarafından kavranabileceğine ilişkin en kapsamlı iddiadır. Gerçekliği kavrama ve bilme insan etkinliğinin yaratıcılı̆̆ını derinleştirmenin ve kendisi de dahil olmak üzere dünyayı olağandan daha huzl- dönüştürebilmesinin temelidir. Bizzat Marx ve Engels'in yazılarıyla ortaya koydukları ve sonrasında da bu damar içinde yer alan siyasal ve entelektüel etkinliklerle geliştirilen Marksizmin, 'bilme/anlama yöntemi", Marx tarafından bütünsel biçimde sadece, tüm diğer ilişki biçimlerinin temeli olarak üretim ilişkilerinin çözümlenmesinde kullanulmıştır. Bununla birlikte, siyaset, din ve hukuk gibi ilk elden karşılaşılan kapsayıcı toplumsal ilişki biçimlerini çözümleme niyeti her zaman için Marx'ın tasarılan arasında yer almıştır. Bir toplumsal ilişki biçimi olarak hukuk, bütünsel bir çalışmanın konusu yapılmamış olmakla birlikte Marx ve Engels'in hukuka ilişkin, değişik konular bağlamında yaptıkları çok önemli saptamaları bulunmaktadır. Bunun ötesinde hukuk Marx'ın düşünsel yapı ve donanımının oluşumunda, kişisel tarihinde çok önemli bir yer işgal etmektedir.

Hukukun, Marx ve Engels tarafından bütünscl bir açılamasının yapılmamıs olması nedeniyle, klasiklere dayanan, bir "Marksist Hukuk Felsefesi"nden söz edilemeyeceği açktır. Ancak, temel hukuk felsefesi akımlarının ayrım noktasının, hukukun kaynağı (tanrısal irade, gelenekler, insan aklı, devletin iradesi vb.) konusunda ortaya çıktı̆̆ gözönüne alındığında, Marx ve Engels'in bu noktaya ilişkin birçok saptamasınun bulunduğu görülmektedir. Marksist Hukuk Felsefesinden söz edilememesinin nedeni, hukukun kaynağına ilişkin sözkonusu saptamaların derinleştirilmemiş ve sistemleştirilmemiş olmasından daha çok, Marx'ın, genel olarak felsefeyi gerçekleştirerek aşma arayışı içinde olmasıdır. Genel olarak felsefe ve özel olarak da hukuk Marksizm için aşılması gereken yabancılaşma alanlarıdır.

Marx ve Engels'in çalışmalarından yola çıkılarak bir hukuk felsefesinin kurulamazlığının yanısıra, Marx ve Engels'in, hukuk genel teorisine, yani 
hukukun temel kavram, kural, ilke ve kategorilerine ilişkin de bütünsel bir çalışması bulunmamaktadır. Üretim ilişkilerinin birincil hukuksal yansımaları olan mülkiyet ve sözleşme kurumları, bu anlamda ayrıcalıklı konulardır. Hukukçulara salt hukuki kavramlar olarak görünen mülkiyet ve sözleşmenin üretim ilişkileriyle bağlantısına ilişkin birçok saptama Marx ve Engels'in yazılannda bulunmaktadır.

Marx ve Engels'in hukuk konusundaki incelemelerinin temel saiki hiçbir zaman derinlemesine bir hukuk incelemesi yapmak olmamıştır. Marksizmin hukukla temel derdi, dünyaya hukuksal bakışın yanlışığını saptamaktr. Hukuk, bu amacın dışında başlı başına bütünsel bir incelemenin konusu yapılmamıştır.

Özetle, Marx ve Engels'in çalışmalarında, bir hukuk felsefesi inşa etme çabası olmadığı gibi, hukukun sistemli ve bütünsel bir çözümlemesi bulunmamaktadır. Ayrıca, kapitalizmi aşma sürecinde veya aşmış olan bir toplumsal yapıda nasıl bir hukuk oluşacağına veya oluşup oluşmayacağına ilişkin de yeterli açıklık yoktur. Hukuk sözkonusu olduğunda Marksizmin temel uğraşı hukuksal dünya anlayışınn eleştirisidir.

Aşağıda bu çerçevede bir değerlendirme yapılacak; çalı̧̧mada, sadece Marx ve Engels'in yazıları esas alınacak; anlatım kolaylı̆̆ı sağlanması amacıyla, "Marksizm" terimiyle de Marx ve Engels'in çalışmaları anlatılacaktır.

Bu basitleştirmenin, araşturmayı sıurlandırma ve kolaylaştırma gibi pratik bir arayı̧ olmasının yanısıra, daha önemlisi, tarihsel/siyasal bir nedeni de bulunmaktadır. Marksizmi, siyasal faaliyetlerinin yöntemi olarak kullanan siyasal örgütlenmenin gerçekleştirdiği 1917 Devriminden sonra, hukuk alanunda yaşanan gelişmeler, hukukun Marksizmle olan ilişkisinin yorumlanması sorununun ne denli önemli olduğunu göstermiştir.

Devrim sonrasından başlayan ve 1936 Stalin Anayasası ile (veya Stalin'in Mart 1939 konuşması ile) sona eren dönemde, hukuksal anlayışlar arasında, aslında devletin kaderi konusundaki tartışmayla doğrudan bağlantılı olan şiddetli bir siyasal/hukuksal çatışma yaşanmıştır. Bu dönemde Sovyet hukuk uygulaması ve kuramina, önemli temsilcileri Stucka, Kursky, Krylenko, Akulov ve Pasukanis olan -daha sonradan "revizyonist" olarak suçlanan- "meta mübadelesi okulu" olarak adlandırlabilecek bir akım damgasını vurmuştur. (Komünist Akademideki görevi, Adalet Komiseri yardımcılığı ve yazdığı adlı kitabıyla, bu okulun en etkili üyesi Pasukanis olmuştur.) Bu akım, Stalin'in 1936 Anayasası hazırlanurken saptadığ1 "hukuksal istikrar" ihtiyacı çerçevesinde girişilen ve 1938 Haziranında "tek bir Marksist-Leninist bilimsel hukuk çizgisi" belirleyen "Sovyet Devlet ve Hukuk Biliminin Sorunları Konferansı" ile sonuçlanan hukuk savaşımında temsilcileriyle birlikte tasfiye edilmiştir. "Meta 
mübadelesi" okulunun temel tezine göre, hukuk genel teorisi alanunda Marksist yazın çok sınurlıdır; ancak, Marx'ın, toplumsal ilişkilerin kökenini araştırmak için kullandiğı mübadele ilişkilerini esas alma yöntemi, hukuksal ilişkileri açıklamak için de kullanulabilir. Daha önemlisi, bu anlayışa göre, meta mübadelesinden köken alan hukuk, sosyalist toplumda sosyalist hukuka dönüşmeyecektir. Sosyalist topluma geçiş sürecinde, kapitalist mübadele ilişkilerinin ortadan kaldırılmasıyla, bunun biçimi olan hukuk da yavaş yavaş sönümlenecek ve üretim/değişimden köken alan ilişkileri düzenleyen kurallar mühendislik, tıp vb. kuralları gibi, salt teknik kurallara dönüşecektir (bkz.PASUKANIS, 1970). Komünist Akademiye de hakim olan bu okulun anlayışına göre, " sosyalist hukuk" veya "iş̧̧i sınıfı hukuku" yaratılması mümkün değildir. Bu anlayış kendini, burjuva hukukunun klasik ilkelerine bağlı kalmak zorunda hissetmemiş, örneğin, suçların yasallığı ilkesini içermeyen, kıyas imkanın öngören bir ceza kanunu tasanısı hazırlamıştır. Hukuksal biçimler, burjuva hukukundan ödünç alınmıştır, içerik yani kapitalist üretim ilişkileri aşıldıkça devletle birlikte hukuk da sönümlenecektir.

$\mathrm{Bu}$ okulun ve temsilcilerinin sonunu hazırlayan temel ayrum noktasi devletin ve hukukun sönümlenmesi konusunda ortaya çıkmaktadır. Engels'in Anti-Duhring'te (1878) yer alan, "iş̧i sinıfı, devlet iktidarnn ele geçirir ve ilk elde üretim araçlarını devlet mülkiyetine dönüştürür... Insanların yönetiminin yerini, şeylerin ve üretim sürecinin yönetimini alır. Devlet, ortadan kaldirlmaz, devlet sönümlenir" (ENGELS, 1995: 400) saptamasından yola çıkan bu anlayış, sosyalist devletin ihtiyaçlarına uygun bir hukuk yaratma ve bunun teorisini yapma yerine, hukukun sönümlenmesinin teorisini yapmaya çalışmış; işçi sınıfı hukukundan söz edilemeyeceği, sosyalist devrimin amacının devletin ve hukukun ortadan kaldırılması olduğu görüşünü savunmuştur. 1930 yılında Stalin'in, "devletin sönümlenmesini hazırlamak için, şimdiye kadar varolmuş en sert ve güçlü devlet iktidarı" tezi, sözkonusu hukukçuların arayışının, resmi arayışla artık örtüşmediğini göstermiştir. 1937 yılında Pravda'da Pasukanis aleyhinde yayımlanan makaleler, kesin tasfiyeyi başlatmıştır. Buradaki temel sav, "Marksist yazının, bir Sovyet hukuk felsefesi yaratmak için yetersiz oluduğu" görüşünün reddedilmesidir. Buna göre, işçi sinıfı diktatörlüğüne dayanan devlet yeni bir devlettir ve bu devlettin yarattığı hukuk da yeni bir tip hukuktur; Marx, Engels, Lenin ve Stalin'in ürünleri bu yeni toplumun hukuk düzenini açıklamak için yeterlidir. Bundan sonra, Pasukanis'in yerini alan Vyshinsky liderliğinde, tek bir bilimsel sosyalist hukuk anlayışı benimsenmiş, Pasukanis yargilanarak, "Sovyet Devleti'nin dayandığı hukuksal temelleri baltaladığı, Sovyet hükümetini devirmek amacıyla hukuksal tcoriler geliştirdiğgi" için ihanetten mahkum olmuş ve idam edilmiştir. Dönem, Stalin'in, 1939 yılında 18. Kongre'de, "kapitalist devletlerle çevrili bir ülkede, bu durum sürdüğü 
sürece, komünist aşamaya geçilse bile, devletin varlığın güçlü biçimde sürdüreceği" tezini savunmasıyla kesin olarak kapanmıştır. ${ }^{1}$

Özetle, Marksizmden düşünsel köken alan bir siyasal devrim, devletin ve hukukun aşılması anlayışı ile devrimin yarattığı yeni yapıya uygun bir devlet ve hukuk teorisi yaratma arayışı arasında bir bocalama yaşamıs, burada incelenmesi mümkün olmayan nedenlerle, ikinci tez hakim olmuştur. llk tez, Marksist yazından kalkarak, kapitalizm sonrası yapıya ilişkin yeni bir hukuk teorisi inşa edilemeyeceğini, zira, bu yeni dönemde devletin ve hukukun sönümlenmesine doğru ilerleneceğini savunurken; ikinci tez de Marksist yazından kalkarak, sönümlenme hedefi bulunmayan, bir sosyalist hukuk teorisi inşa edilebileceğini savunmaktadır.

Günümüz Türkiye'sinde birçok sol muhalif akımın, siyaset çizgisini hukuk devletinin ve insan haklarınun savunusuna indirgemiş olması, hukukun Marksist kavranışını güncel hale getirmektedir.

Bunun ötesinde, hukukun Marksist yöntemle incelenmesi henüz tatmin edilmemiş bir ihtiyaçhr. Dünyanun bütünsel kavranışını hedefleyen bir yöntemin, hukuka bu kadar yabancı kabul edilmesi aşılması gereken bir yanilgidir.

llk adım olarak, aşağıda, Marx ve Engcls'in çalışmalarında hukuk konusunun nasıl ele alındığına ilişkin bir tarama yapılacaktır. Sadece Marx ve Engels ile sınırlı kalınacak, Lenin'in çalışmalarına ve Sovyet Devrimi'ne, Pasukanis'e ve diğer teorisyenlere başvurulmayacaktır. İkinci aşama olarak, klasik metinlerin dişında, Marksizm ve hukuk ilişkisini ele alan kitapların değerlendirildiği bir yazı tasarlanmaktadır.

\section{Marx'ın Kişisel Gelişiminde Hukuk}

Marksizm'in hukuk anlayışının ne olduğunu, Marx'ın kişisel gelişiminde hukukun yerini incelemeden araştırmak mümkün değildir. Babası da hukukçu olan Marx, Üniversite'de hukuk eğitimi almıştır. Marx'ı, Hegel'i incelemeye ve sorgulamaya yönelten de hukuk alanındaki arayışlarıdır. Marx, üniversiteye girerken meslek olarak hukukçuluğu tercih etmektedir. Felsefe doktorasıyla üniversite eğitimini tamamlayan ve Prusya Devletinin Üniversite tasfiyesi nedeniyle akademik kariyer yapamayan Marx'in gazetecilik yıllarındaki yazı konuları da hukuksal/siyasal konulardır.

'1 Sovyet Devrimi sonrası yaşanan bu hukuksal mücadeleyi, "revizyonist hukuk anlayışına karşı mücadele" bakış açısından, çok iyi özetleyen bir yazı için bkz. The Marxist-Leninist Research Bureau, Marxism and Law (The Struggle Over Jurisprudence in the Soviet Union), http//website.lineone.net/ comleague/intercom/law.html , 8.2.2002 
Her ne kadar hukuk alanundaki incelemeleri çok hızlı biçimde geride bırakmış olsa da Marx’ın birçok yazısında, kısa fakat önemli hukuksal değerlendirmeler yer almaktadır.

\section{A. Hukuk Öğrencisi Marx}

Marx'ın, üniversite eğitiminin ilk yılının sonunda babasına yazdığı 10 Kasım 1837 tarihli mektubu, "hukukçu geçmişini" ve hukuka bakış açısını göstermesi açısından önemli bir kaynaktır (MARX, 1837). ${ }^{2}$ Yazdıklarında, neden hukukçu olmadığına ve hukuki yaklaşımı nasıl aştığına ilişkin ipuçları da bulunmaktadir. Bu mektubu, uzunca altınlar yapmayı ve okuyucuyu sıkmayı da göze alarak biraz ayrıntılı incelemenin önemli olduğunu düşünüyorum.

Marx'ın babası Heinrich Marx, Yüksek Temyiz Mahkemesindeki davalarda görev alan bir avukattır. Marx, babasının tercihi doğrultusunda, hukuk öğrenimi için 1835 yllında Bonn'a gitmiş, 1836 yllında ise hukuk öğrenimini tamamlamak üzere Berlin Üniversitesine geçmiştir (STMA I: 40-41).

Berlin'de geçirdiği bir yılın sonunda Marx, babasından gelen mektuba da yanit vermek amaciyla, sanat ve bilimdeki entelektüel faaliyetlerinin ve özel konuların bir muhascbesini yapmak üzere inceleyeceğimiz mektubunu yazmıştır.

Marks, mektubuna, "hayatta dönüm noktalan vardır, bir dönemin kapanıp yeni bir yönelişin açlışını gösteren dönem noktaları vardır" diye başlıyor. Jenny'e olan aşkının hayatını değiştirdiğini, Berlin'e geldikten sonra çevreyle bağlarını kopardığını, pek gezmediğini, bilim ve sanatta yoğunlaşmaya çalıştığını söylüyor.

Marx'ın ilk sorgulaması ve kopuşu edebiyat çalışmalarındaki tarzına ilişkin. Ortaya koyduğu tüm sanatsal uğraş ve ürünlerinin gerçek dünyadan kopuk olduğunu fark ediyor. Bu konuda babasına şöyle yazıyor Marx: "o zamandaki ruh halime uygun olarak, lirik şiir temel, enazından en zevk aldiğım uğraşımdı. Fakat yaklaşımım tamamen idealist nitelikteydi. Sanatım, aşkım kadar uzak bir dünyaya dönüşmüş̧ü. Gerçek olan herşey puslu bir hal aldı ve puslu olan da kesin sinırlardan yoksundu." Marx, ürünlerinin (şiirlerini) gerçeklikten, gerçek dünyadan kopuk olduğunu fark ederek bir hayal kırıklığı yaşıyor.

Aynı durum, Marx'ın hukuk alanundaki çabaları için de geçerlidir.

2 Mektup Latince yazılmıştır. Ilkez 1897 yulında yayımlanan bu mektuba, Marksizm ve hukuk konusundaki tartışmalar bağlamında hiç değinilmemeḳtedir. Örneğin, Marksizm ve hukuk konusundaki en kapsamlı çalışmlardan biri olarak kabul edilen, Stoyanovic'in, Marxisme et Droit adl eserinde bu mektuba hiç değinilmemektedir. Ayrıca, (COLLINS, 1982). 
Marx, şiirin bir yan uğraş olduğunu asıl işinin hukuk öğrenimi görmek olduğunu söylerek babasına, yaptıklarını anlatıyor: "Hukuk çalışmalı ve hepsinden öte felsefeyle cebelleşmeliydim. Bu ikisi sıkı biçimde ilişkiliydi. Bir yandan Heineccius, Thibaut ve diğer kaynakları, bir okul çocuğu gibi pek de eleştirel olmayan bir tarzda okudum, öte yandan da hukukun tüm alanlannı kapsayan bir hukuk felsefesi hazırlamaya çalışıım."

Hukuk öğrencisi Marx, hukukla düşünsel bağlantısını, olağan bir hukuk öğrencisinden beklenebilecek şekilde hukuk dogmatiği alanından değil de felsefeden kurmakta; hatta bir hukuk felsefesi kitabı hazırlamaya çalşmaktadır. Marx, kitabının, tüm hukuk alanlarını kapsadığın, kitaba, metafizik önermelerle bir giriş yaptığını, bu "umutsuz" esere kamu hukukunu bile aldığını ve kitabın yaklaşık üç yüz sayfayı bulduğunu belirtiyor. Marx'ın bu çalı̧̧ması, günümüze ulaşmamıştur.

Marx, sanatta olduğu gibi hukuktaki çalışmalarının da eleştirisini yaparak fikri gelişiminde bir sıçrama gerçekleştirmiştir. Şiirlerinde olduğu gibi yazdığı hukuk kitabında da "idealizmin tipik özelliği olan, olmast gereken ile olan arasındaki karşıtlı̆̆ı önemli bir kusur olarak ortaya çıkı̆̆ını", bunun "konunun yanlış bölümlenmesinin nedeni olduğunu" söylerek çalı̧masını eleştirmektedir. "Ilk olarak, 'hukukun metafiziği' olarak nitelediğim, tüm gerçek hukuktan ve tüm gerçek hukuk biçimlerinden kopmuş 'temel ilkeler, tanımlar ve fikirler' aktarlmıştı. Temel hata, konuyu yaşayan ve çok yönlü gelişen birşey olarak ele almak yerine bir 'matematiksel dogmatizm'e düşmekti. Konu, yaşayan düşünceler dünyasımın bir bütün olarak, hukuk, devlet, doğa ve felsefede örneklenen somut ifadesinde, kendi gelişimi içinde incelenmeli; keyfi bölümlemeler yaplmamal, konunun rasyonel nitelï̆i, çelişkilerle yoğrulmuş kendi içinde bütünlüğe ulaşmı̧ birşey olarak gelişstirilmelidir."

Marx, hukukun durağan bir teorisinin yapılmasına karşı çıkmaktadır. Kitabında böyle bir işe girişmiş olmasına karşın, daha sonra, "hukukun genel kavramları" gibi bir kavramlaştırmanun, teorik bir çerçeve olmayıp bir idealizm olduğu sonucuna varmaktadır. Soyutlamaları, soyutlanandan kopararak derinleştirmek, kendi içinde bir amaca dönüştürmek, araştırıcıyı, "ide"lere götürmektedir.

Kendi kitabına ilişkin köklü eleştirilerini sürdüren Marx, bir diğer hata olarak da biçimsel hukuk ile maddi hukuk arasında ayrım yapmış olmasını göstermektedir. Ona göre, hatasının nedeni, konu (madde) ile biçimin birbirinden ayrı olarak gelişebileceği ve gelişmesi gerektiği inancıdır.

Marx, sözkonusu kitabında, hukuku tasnif ederken, hukukun failini esas almaktadır: Akdi hukuk, akdi olmayan hukuk. Bu çerçevede kamu hukuku, özel hukuk ayrımının kullanılabileceğini kabul edip bunun üzerinden bir plan benimsemektedir. Mektubuna aktardığı planında özel hukuk bölümünün ayrıntısı bulunmakla birlikte kamu hukuku başlığı altında birşey bulunmamaktadir. 
Marx, özel hukuka ilişkin ayrıntılı planını mektupta aktardıktan sonra, kendisine, "neden reddettiğim şeylerle sayfalart doldurmak zorunda olayım $k i "$ sorusunu sorduğunu, özel hukuka ilişkin bölümün sonunda herşeyin yanlı̧ olduğunu gördügüünü yazıyor. "Felsefe olmadan ilerlenemeyeceğini yeniden anladım, yeniden felsefeye sanldım ve metafizik ilkeler sistemi tasarladım, ama bir kez daha bunun yanlış olduğunu anlamak zorunda kaldım." Bu hayal kırıklığından sonra tekrar edebiyatla uğraşmaya başladığını belirtiyor.

Geceler boyu çalışmaları nedeniyle içine kapandığın, zenginleşemediğini, aksine doğayı, sanatı ve dünyayı ihmal etmiş olduğunu yazıyor babasına. Bedence de zayıflayan Marx, doktorunun kira gitmesi önerisi üzerine bu ortamdan sıyrılıyor: "böylece kenti bir baştan başa ilk kez geçerek Stralow'a gittim. Buradan güçlenerek, olgunlaşarak döneceğimi sanmıyordum. Ama bir perde indi, kutsal değerlerim paramparça oldu ve yeni tanrlar onlann yerini ald. Kant ve Fichte ile kıyaslayıp beslediğim Idealizmden, idealan gerçekliğin kendi içinde arama noktasına geldim."

Stralow'da Hegel felsefesinden parçalar okuyan Marx, bunlara ilişkin olarak mektubunda, "bana hitap etmeyen grotesk kaba ezgiler. Benim amacum dalaverelerle uğraşmak değil, artık gerçek değerler yaratmak istiyorum" değerlendirmesini yapıyor. Birbirinden tamamen ayrılmış olan sanat ve bilimi bir ölçüde birleştirmeye çalışan 24 sayfalık bir diyalog yazıyor. Ancak çok değer verdiği bu çalışmasının da aslında "onu düşmanın kollarına çă̆ıran bir denizkızı " olduğunu fark ediyor.

Bir süre kızgınlıkla çalışamayan Marx, daha sonra kendisini pozitif hukuk okumalarına veriyor. Burada da umduğunu bulamayan Marx, tüm bu "verimsiz çalş̧malannın" ve Jenny'nin hastalığının getirdiği üzüntü nedeniyle hasta düştüğünü ve bu ruh hali içinde, şiirlerini ve tüm diğer çalışmaların yaktığını yazıyor babasına. Marx bu hastalığı sırasında, daha önce parçalar okuduğu, Hegel'i ve takipçilerinin çoğunu öğrendiğini de belirtmektedir.

Görüldüğü gibi Marx'ın, bilginin kaynağına, nasıl araştırılıp, sistemleştirilip aktarılabileceğine ilişkin temel kayglları, hukuk konusu bağlamında ortaya çımıştır. Hukuk üzerindeki çalışmalan, idealizmden kopuşunun çıkış noktasını oluşturmuş ve bunun yönlendiricisi olmuştur.

Mektubunun ilginç bir bölümü de Marx'ın, eğitim yapacağı alanın hukuk olması konusundaki kararlılığın göstermektedir. Hayatının sonraki aşamalarında, hiçbir zaman hukukçuluk yapmayacak ve hukuksal dünya kurgusundan da düşünsel olarak hızla ve sürckli uzaklaşacak olan bir insanın, babasına karşı, idari bilimler eğitimine kıyasla hukuk eğitimini savunması ilginçtir. Marx, maliye alanında kariyer yapmak için, idari bilim okumak istemediğini söyleyip, hukuk okuyarak da maliyeci olunabileceğine, hatta ilerde doktora da yaparsa iyi olanaklar da bulunduğuna, örnckler vererek, babasını 
inandırmaya çalışmaktadır. Bu konudaki sözünü şöyle bitirmektedir: "Gerçekten, hukuku, tüm idari bilimlere tercih ederim".

Marx, 1836 yllında girdiği Berlin Üniversitesi Hukuk Fakültesi'nden 1841 Nisanunda mezun olmuş; Nisan 15'te de, 1839-41 yıllarında çalıştığı felsefe tarihi (özellikle Antikite) ile ilgili bir konuda yazdığı (Demokratus ve Epikür Doğa Felsefelerinin Farkı başlıklı) doktora tezi Jena Üniversitesi'nde kabul edilmiştir.

\section{B. Hukuksal Bakış Açısından Kopuş}

\section{Gazetecilik Yılları}

Hukuk fakültesinde okuyan Marx, ilk yılında hukuka ilişkin çalışmalara yönelmiş olmakla birlikte, daha sonra, bu alanın verimli olmadığını görerek ilgisini felsefe ve felsefe tarihine kaydırmıştır. Doktora tezi de hukukla ilgili değildir. Ancak, Marx'ın üniversite sonrası yazarlık ve gazetecilik yapması, onun siyasal faaliyetlere ve ele aldığı konular dolayısıyla da tekrar hukuka yönelmesi sonucunu doğurmuştur.

Jena Üniversitesi'nde felsefe dalında doktora tezini veren Marx, Temmuz 1841 'de üniversitede felsefe alanında kariyer yapma düşüncesiyle Bonn'a gitmiş ancak, 1840'larda Prusya monarşisinin izlemekte olduğu politikalar, liberal görüşlerin üniversitelerde barınmasını olanaksız kıldığından akademik kariyer yapma imkanı bulamamıştır (STMA I: 48).

Üniversitede çalışma imkanu bulamayan Marx, Prusya Kralı IV.Friedrich Wilheim'in gerici-baskıcı yönetimine muhalefet etmek için liberal burjuvalar tarafından yayımlanan ve Genç-Hegelcilerden entelektüel destek alan Rheinische Zeitung'da, yazmaya başlar.

Bu yeni süreçteki faaliyetleri, sürekli biçimde Prusya devleti ile yüzyüze gelmesine yol açmış; bu da Marx'ı devleti ve hukuku sorgulamaya yöneltmiştir.

Ilk yazısı, 2 Mayıs 1842'de yayımlanır. 15 Ekimde Gazete'nin yayın yönetmeni olur. "Marx'in bu dönemde siyasal görüşlerini içeren ilk makalesi Prusya Hükümeti'nin 24 Aralık 1841 'de yayınladığı sansür yönetmeliği üzerine, daha 1842'nin ilk aylarında yazmış olduğu 'Son Prusya Sansür Yönetmeliğine Karşı Düşünceler' başlıklı yazısıdır. ... Eleştirisinde vurguladığı nokta devlet ve birey arasındaki ilişkilerin keyfilliği ve eşitsizliğidir (STMA I: 51-52)." Prusya Devletinin sansürüne ilişkin yazılarına devam eder. Devlet ve sinıfsallık arasındaki bağlantı üzerine düşünmesine yol açan bir diğer konu da "yakacak yokluğu yüzünden ormanlardan kuru dallar toplayan köylülerin, bu ormanlar özel mülk olduğu için cezalandırılmaların" düzenleyen bir yasanın meclis görüşmeleridir. "Marx'in bu konudaki makaleleri, devlet ile özel mülkiyet, Prusya monarşisi ile toplumu oluşturan çeşitli sınıflar arasındaki ilişkileri ilk kez 
dile getirmeleriyle dikkat çeker (STMA I: 54)." Gazete, onun yönetimi altında demokratik ve devrimci bir çizgi izlemiştir. 1943'de hükümet gazeteyi yasaklama kararı alır. Polis baskısı nedeniyle yayın imkansızlaşmıştır. Ayrıca "gazetenin 12 Şubat 1943'te yapılan olağanüstü genel toplantısında, mali kaynakları sağlayan liberal işadamları gazeteyi kurtarmak için çizgisinin yumuşatılmasından medet umduklarını açıķa ortaya koyunca, Marx gazetedeki görevinden ve liberal siyaset çevrelerinden, geri dönmemek üzere ayrılmıştır.

Görüldüğü gibi, Marx'ın üniversite yıllarındaki düşünsel çalışmalarının kalkıs noktası, "hukuku" anlama çabasıdır; ayrıca, Marx, üniversiteden hemen sonra gazetecilikle başlayan siyasal faaliyetlerinde de sıklkla Prusya devletinin siyasal/hukuksal uygulamaları üzerine yazılar yazmıştır.

Gerek babasına mektubunda aktardığı hukuka ilişkin inceleme planı, gerck Hegel'in Hukuk Felsefesinin Eleştirisindeki değerlendirmeleri, hukukun anlaşılması ve doğru kavramlaştırılmış bir hukuki yaklaşım oluşturulmasına yönelik verimli sonuçlar üretememiştir.

Marksizm ve hukuk dendiğinde yapilabilecek temel saptama, Marksizmin, dünyanın hukukçu bakış açısıyla açılanıp anlamlandırabileceğini reddetmesidir. Bunun dışında, hukukun kaynağının salt iradede aranmaması gerektiği Marksizmin hukuk konusundaki ikinci temel tezidir. Bu temel saptamalar ötesinde Marksizmin, bir hukuk felsefesi/kuramı kurmadığı açıktır.

\section{Hukuk Incelemelerinden Siyasal iktisat Eleştirisine}

Gazeteden aynlması köşesine çckilip felsefi çalışmalarını yoğunlaştırması için bir fırsat yaratmıştır Marx için. Ilk derinleştiği konu hukuktur ve vardığı sonuçlar hukukun ötesine geçip hukukçunun dar bakıs açısından kurtulmasını sağlamıştır.

Gazeteden ayrıldıktan sonra, kuramsal çalı̧̧malara dönen Marx, gazeteciliği sırasında Prusya devletinin idari/hukuki baskısıyla tanı̧̧ı̧̧ olmasından olsa gerek, Hegel eleştirisine devlet ve hukuk felscfesinden başlamıştır.

Ancak Marx'in, Hegel'in Hukuk Felsefesi'nin Eleştirisine Katkı (1843) çalışması da yarım kalmıştır. Bu noktadan sonra hukuk, Marx'ın temel uğraş konularından biri olmaktan çıkmıştır. Marx'ın kendi özgün düşünce sistemini kurma yolunda, hukuk durağından sonraki ikinci uğrağı burjuva siyasal iktisadının eleştirisi olacaktır. Hukukun doğru biçimde algılanması ve varılan sonucun dünyanın anlaşılmasında kullanılması çabasının doğası gereği yetersiz sonuçlar doğurması Marx'in yönelim değiş̧tirmesini gerektirmiştir. 
Marx, Ekonomi Politiğin Eleştirisi'ne Katki'nun (1859) Önsözünde, araştırmalannın çıkıs noktasının hukuk olduğunu açıkça ortaya koymaktadır: "Benim uzmanlaşmış çalı̧̧alarımın konusu, felsefe ve tarih yanında ikincil bir bilgi kolu saymıs olmama karşın hukuktu. ... Kafamda biriken kuşkulan gidermek için ilk giriştiğim çalışma, Hegelci Hukuk Felsefesi'ni, eleştirici bir gözle yeniden gözden geçirmek oldu (MARX, 1993:22)." Ekonomi Politiz̆in Eleştirisi'ne Katk'y1, Marx'ın, hukuksal çıkış noktasını kendisinin de açıkça ortaya koyduğunu saptamak için kısa bir alıntıyla geçiyoruz. Bu çalışmada yer alan, hukuk konusundaki temel tezler aşağıda incelenecektir.

Marx, siyasal iktisat konusundaki bu çalı̧̧ması ile hukukçuluğunu ve hukuki araştırmaların tamamen terk etmiştir.

Kapsamlı bir hukuk eleştirisi yapmak başlarda Marx'ın amaçları arasında yer almaktadır. Ancak, hukuk, din ve siyasal iktisat güzergahunda ilerleyen çalışmaları, bir daha geri dönmesini imkansız (ve belki de kendisi için gereksiz) kılacak denli derinleşmiş ve projeleri arasında yer almakla birlikte hukuk eleştirisini hiçbir zaman gerçckleştirememiştir. Ölümünden sonra Hegel'in Hukuk Felsefesinin Eleştirisi (1843), adıyla yayımlanan çalışması ise bir hukuk eleştirisi değildir. Eleştirinin, Fransız Alman Yıllıklarında Marx'ın sağlığında yayımlanan, "Girişi" bir din eleştirisidir; ana metin ise, özgün bir kurgudan yoksun, Hegel'den alıntılanan pasajlara ilişkin kısa değerlendirmelerden oluşan tamamlanmamıs notlardır.

Marx, 1843 tarihli Hegel'in Hukuk Felsefesinin Eleştirisi'nden sonraki çalışması olan 1844 Iktisadi ve Felsefi Elyazmalarinın önsözünde, hukuk konusunda eleştirel bir çalı̧̧ma planından söz etmektedir: "Alman-Fransız Yılliklari'nda Hegel'in Hukuk Felsefesinin bir eleştirisi biçimi altında, hukuk bilimi ile siyasal bilimin eleştirisini haber vermiştim. ${ }^{3}$ Elyazmasını baskı için hazırlarken, ${ }^{4}$ kurgusal felsefeden başka bir konusu olmayan eleştiriyi, çeşitli konularm eleştirisine kanş̧tırmanin büsbütün yersiz olduğu ve bu karışımın açıklamayı engelleyip anlaşılmasını güçleştirdiği ortaya çıktı. Incelenecek konularn zenginlik ve çeşitliliği, bunların tek bir yaptt içinde toplanmasına ancak özdeyişler biçimi altında izin verirdi ve bu türlü bir açıklama yöntemi keyfe bağlı bir sistemleştirme görünüşüne bürünürdü. Bu nedenle, hukuk, sağtöre, siyaset vb. eleştirisini ayrı ayrı broşüler biçimi altında ardardına verecek ve tamamlamak için, özel bir çalışmada, bütünün zincirlenişini, çeşitli bölümlerin birbirleri arasındaki ilişkiyi kurmaya çalışacak ve bitirmek için de kurgusal felsefenin bu gerȩ̧ üzerinde çalışma biçimini eleştireceğim ${ }^{5}$ (MARX, 1976: 91)."

3 Marx burada, Fransız-Alman Yilliklarinda yayınlanmıs bulunan "Hegel'in Hukuk Felsefesinin Eleştirisine Katkı. Giriş" başlıklı makalesine anıştırmada bulunmaktadır.

4 Marx'ın burada 1843 yazı içinde yazdığı, ama ancak 1927'de yayınlanmış bulunan Hegel' in Hukuk Felsefesinin Eleştirisine Katki'yı düşünmcsi olasıdır.

5 Bu plan hiç bir zaman gerçekleşmedi, ama Kutsal Aile ile Alman Ideolojisi Hegel felsefesinin eleştirisine birer katkı da sayılabilirler. 
Nitekim Marx'ın, böylesi bir bütünsel yaklaşımla kurguladığı yarım kalmış bir çalışması da bulunmaktadır. Ekonomi Politiğin Eleştirisine Giriş (1857) çalışmasında, hukuka ilişkin, tamamlanmamış bir bölüm bulunmaktadır. Ekonomi Politĭ̌in Eleştirisine Giriş (1857) Marx'ın sağlığında yayınlanmamış, tamamlanmamış notlardır. Hukuku, bütünsel incelemede nereye koyduğunu göstermek için kitabın planunı aktarmanın yararlı olacağını düşünüyorum. Inceleme dört başlıktan oluşmaktadır. Illk bölüm "genel olarak üretim"; ikinci bölüm, "dağıtım, mübadele ve tüketim arasındaki ilişki"; üçüncü bölüm, "ekonomi politiž̆in yöntemi" ve sadece karalamalar biçiminde kalmış olan dördüncü bölüm ise "üretim araçlarn, üretim ilişkileri. Üretim ilişkileri ve toplumsal kurumlar. Üretim ilişkileri ve toplumsal kurumlarla ilişkileri içinde devlet ve bilinç biçimleri. Hukuk. Aile" başlığını taşımaktadır. Bu son bölüm sadece başlıktan ve kısa bir nottan ibaret olarak kalmıştır. Marx siyasal iktisat incelemesinde, hukuku da üretici güçler ve üretim ilişkileri bağlantısı içinde incelemeyi planlamış; gerçekleşmemiş bu plandan geriye şu kısa not kalmıştır. Marx'ın bu dördüncü başlıkta "unutulmaması ve burada ele alınması gereken noktalar" arasındaki altıncı notu şöyle: "Maddi üretimin gelişmesi ile örneğin sanat üretiminin gelişmesi arasındaki eşit olmayan ilişki. ... Asıl gǚçlük şudur: üretim ilişkilerinin nasıl olup da hukuki ilişkiler biçimine bürününce eşit olmayan bir gelişme izlediklerini anlayabilmektir. Örneğin, Roma özel hukuku ile (ceza ve kamu hukuku için bu daha az geçerlidir) modern üretim arasındaki ilişki (MARX, 1998: 482; MARX, 1993: 248)."

Marx, Hegel'i eleştirerek hukuk ve siyasal bilim eleştirisi yapmayı amaçlamışt. Ancak yayınlamadan önce çalışmalarını inceleyince yapmış olduğu eleştirisinin asıl konusunun kurgusal felsefe olduğunu görmüş ve hukuku ayrıca incelemeyi planlamıştır. Marx bu planını hiçbir zaman gerçekleştirmemiştir. Burada, Marx'ın neden hukuk eleştirisine tekrar dönmediği sorusu akla gelmektedir. Artan siyasal faaliyetleri nedeniyle zaman mı bulamamıştır, yoksa hukuk eleştirisini verimli bir alan olarak mi görmemektedir? Hukuk, siyaset, ahlak, din vb.lerinin kökenini bulduğunu, bunların yalnızca bu temelin/ kökenin "ifadesi" olduğunu söyleyen bir düşünürün, çalışmalarını kökene yöneltmesi doğaldır.

\section{Marx/Engels'in Hukuk Konusunda Değerlendirmeleri}

\section{A. Temel tez: Hukuksal Dünya Görüß̧ünün Eleştirisi}

Marksizmin hukukla temel derdi, dünyaya hukuksal bakışın, dünyanın hukuksal algılanmasını eleştirisidir. Marx bu yöntemin yanlışlı̆̆ın saptadıktan sonra, burada derinleşmemiş ve hukuk üzerinde daha fazla durmadan ilerlemiştir. 
dır: "Ortaçağda dünya anlayışı temelde tann bilimciydi. ... Avrupa dünyası birliğinin potası katoliklik olmuştu." Sadece düşünsel bir gü̧̧ değildi bu, "herşeyden önce feodal ve hiyerarşik biçimde örgütlenmiş ve toprağın yaklaşık üçte birinin sahibi olmast sifatiyla, her ülkede feodal örgütlenme içinde çok büyük bir siyasal gücü elinde bulunduran kilise" gerçek bir bağ yaratıyordu. "Feodal toprak sahipliği ile kilise, feodal örgütlenmesi dinsel olmayan feodal devlet sistemini dinsel olarak kutsuyordu. Aynca papazlar sinıfı tek eğitilmiş sinıftı." Kilisenin bu baskm konumu düşünce yapısına da tanrıbilimci doğmanın damgasın vuruyordu. "Her düşüncenin hareket noktasının ve temelinin kilise doğması olması gereği doğal birşeydi. Hukuk, doğabilimi, felsefe, her bilgiye uygulanan ölçü aynıydı: içeriği kilisenin öğretimine uyuyor mu uymuyor mu? (ENGELS/KAUTSKY, 1995: 250-1)"

Ancak "feodalizmin ölçülerine göre biçilmiş katolik dünya anlayışı", feodalitenin bağrindan doğan yeni sinıf burjuvaziye "onun üretim ve değişim koşullarına" yeterli gelmemeye başlamıştı. Burjuvazinin kendisine dar gelen bu çerçeveden çkışı birden gerçekleşmemiştir. Burjuvazi "uzun süre tanrıbilimin tutsağı olarak kalmıştır. ... Onü̧̧üncü yüzyıldan onyedinci yüzyıla kadar, dini sloganlar altında yürütülen bütün reformlar ve savaşımlar, teorik yönden eski tannbilimci dünya anlayışıı yeni ekonomik koşullara ve yeni sınıfin durumuna uygun hale getirmek için burjuvazinin ve kent halkmin ve bunların müttefikleri olan isyance köylülerin yinelenmiş girişimlerinden başka bir şey değildir." Ancak tannbilimsel dünya anlayışıı, yeni sımıfin ihtiyaçlarına uydurma çabası yürümemiş "dinsel sancak Ingiltere'de son kez olarak 17. yüzyzlda dalgalan(mis) ve henüz elli yil sonra burjuvazinin klasik yeni kavramı hukuksal dünya anlayışı Fransa'da açıķ̧a sahneye çık (mıştır)."

Engels/Kautsky, tanrıbilimci dünya anlayışının yerini alarak burjuvazinin temel siyasal aracı olan hukuksal dünya anlayışının özelliklerini de incelemektedir. Buna göre, hukuksal dünya anlayışı, "tanrıbilimci anlayışın dünyasallaştınlmastdır. Dogmanın, tannsal hukukun yerini, insan hukuku; kilisenin yerini devlet al(mıştır)." Bu, basit bir yer değiştirme değildir. İnsanların dünyayı, toplumsal ilişkileri algılayışlarında da bir değişme yaratmaktadır. "Kilise onlara onayın veriyor diye, eskiden kilise ve dogma tarafindan yaratılmıs gibi kabul edilen ekonomik ve toplumsal ilişkiler şimdi hukuk üzerine kurulmuş ve devlet tarafindan yaratılmış olarak kabul edil(-mektedir)."

Hukuk artık burjuva toplumun kurucu öğesi olarak değerlendirilmektedir. Iktisadi ve toplumsal ilişkilerin tanrısal iradenin yaratısı olmadığı anlaşılmıs; ancak kuruculuk rolü hukuka ve dolayısıyla devlete atfedilmiştir. Hukukun, toplumsal ve iktisadi ilişkilerin kurucusu olarak algılanmasının, hukuksal bakı̧̧ açısınun yerleşmesinin temel nedeni özgür meta mübadelesidir. "Metaların özellikle avans ve kredi verilmesiyle kolaylaştırlan toplum ölçeğindeki ve tam gelişme içindeki değişimi, karşılıklı sözleşmeye dayanan karmaşık ilişkiler doğuruyor ve bu nedenle ancak topluluk tarafindan yapilabilecek genel düzeyde kurallar 
Marx, hukuk çalışmalarından kopuş yıllarının bir ürünü olan, Hegel'in Hukuk Felsefesi'nin Eleştirisi'ne Giriş'te (1844) hukuku, din ile birlikte insanın yabanclaşması olarak nitelemiş̧ir. Şu farkla ki din, yabancilaşmanun "kutsal görüntüsü" iken hukuk bu yabancılaşmanın "yercil biçim"lerindendir (MARX, 1997: 193).

Dünyanın açıklanmasında hukuk temel araç olarak kullanılamaz. Örneğin, "mülkiyetin ne olduğunu anlayabilmek için hukuksal yönünü incelemek yeterli değildir. Marx'ın J.-B. Schweitzer'e Mektubu'ndaki (1865) saptamasıyla, Mülkiyetin ne olduğu sorusuna, mülkiyet ilişkilerini, irade iliskilerinin hukuki ifadesinde değil fakat gerçek biçiminde yani üretim ilişkilerinde kavrayan bir eleştirel siyasal iktisat çözümlemesiyle yantt verilebilir (MARX, 1995: 176)."

Marx, dünyanın algılanı̧ında hukukun ideolojik işlev gördüğü saptamasınn yanısıra, son bölümde ele alacağımız gibi, Gotha Programının Eleştirisi'nde (1875), bu bakış açısından kalkılarak tahlil yapılamayacağı ve siyasal program oluşturulamayacağın da savunmaktadır.

Ilk bölümde yaptığımız "Marx'ın kişisel gelişiminde hukuk" değerlendirmesi, temel tezin oluşumu ve hassasiyetler konusunda genel bir açıklk getirmektedir. Bunun dışında bu tezin, en açık ve yalın ortaya konuşu Marx'ın ölümünden sonra Engels ve Kautsky'nin birlikte kaleme aldıkları bir yazıyla gerçekleştirilmiştir. Engels/Kautsky'nin 1887 yılında Neu Zeit'da yayımlanan "Hukukçular Sosyalizmi" başlıklı yazısı, Marksizmin hukuk konusundaki temel derdinin özeti niteliğindedir. Sosyalist mücadelede hukukun ve hukukçunun rolüne ilişkin kısa değerlendirmeler de bulunan yazınun temel tezi, hukuksal dünya görüşünün eleştirisidir.

Makalenin sonunda ortaya konan açık yargı, temel tezi vermektedir: "Burjuvazinin hukuk hayali iş̧i simfinm içinde bulunduğu durumu bütünüyle ifade etmeye yetmez. Iş̧̧i sinifinın kendisi, şeylere ancak kendi gerçeklikleri içinde, hukuksal renklerle boyanmamıs gözlüklerle bakarsa, bu durumu [proleterleşme durumunu -OK] tam olarak tantyabilir." Hukuksal renklerle boyanmamış bakış açısı ise tarihsel maddeciliktir: "Marx materyalist tarih anlayısılyla, insanlarn bütün hukuksal, siyasal, felsefi, dinsel vb. düşüncelerinin, son tahlilde onlann ekonomik yaşam koşullarından, ürünleri üretim ve değişim tarzindan geldiğini tanttlayarak iş̧̧ sinıfina bu iş için yardım et [miştir]" (ENGELS/KAUTSKY, 1995: 253).

Engels/Kautsky, hukuksal dünya anlayışının burjuvazinin dünya anlayışı olduğunu ve işçi sınıfının kendisine benzer bir anlayıs geliştirmesinin gerekmediğini savunmaktadır: "'Hukuksal dünya anlayışı' Ortaçağın 'tanrıbilimci dünya' anlayışından çıkldıktan sonra burjuvazinin yeni ekonomik koşullara uygun dünya anlayışıdır."

Engels/Kautsky, Ortaçağın tanrıbilimci dünya anlayışı ile burjuvazinin hukuksal dünya anlayışının niteliklerini ve toplumsal temelini de açıklamakta- 
-devlet tarafindan saptanan hukuksal normlar-gerektiriyor diye, bu hukuksal normlann kaynă̆ının ekonomik olgular olmadığı, onlann devlet tarafindan resmi olarak ortaya konuldu ̌̆u sanul(tr) (ENGELS/KAUTSKY, 1995: 252)."

Serbest meta mübadelesinin yanısıra, serbest rekabetin eşitlik ilkesini gerektirmesi ve burjuvazinin iktidar için siyasal savaşımının hukuksal talepler olarak dile gelmesi hukuksal dünya anlayışının yerleşmesinin diğer nedenleri olarak ortaya konmaktadir.

Hukuksal dünya anlayışı sadece burjuvazi tarafından benimsenmemiştir. Burjuvazi daha iktidarın sağlamlaştırmadan, "negatif eşi" işçi sınıfının mücadelesiyle karşılaşmıştır. Iş̧̧i şnıfı da mücadelesinde hukuka başvurmuştur: "Nasıl ki eskiden burjuvazi, soyluluğa karşı savaşımında geleneğe uygun olarak tanmbilimci dünya anlayışın belli bir süre daha beraberinde süreklediyse, başlangıçta proleterya da hasmından hukuksal kavramlan al(mıs) ve oradan burjuvaziye karşı silahlar sağlamaya çalış(mıştır)."

Engels/Kautsky, işçi sınıfının burjuvazinin hukuksal dünya anlayışına ait kavramları devralmasını geçici bir durum olarak değerlendirmektedir. İş̧ sınffı, tarihsel maddecilik sayesinde, hukuksal "boyadan" arınmış bir dünya anlayışı oluşturacaktır. Ancak ele aldığımız yazıda, bu anlayışın ne olacağına ilişkin bir açıklama bulunmamaktadır.

Iş̧̧i sınıfınn, burjuvaziden ödünç aldığı kavramlar, burjvazinin kullandiğı şekliyle kullanılmamış, farklı anlamlandırılmaya çalışılmıştır. Iş̧̧ sınıfının ilk siyasal oluşumları ve bunların teorisyenleri, saf hukuki kavramlar üzerinde durmuşlar ancak, onların hukuksallıkları burjuvazininkiyle aynı olmamıştır. Bir yandan eşitlik istemi genişletilmiş, hukuksal eşitliğin toplumsal eşitlikle tamamlanması talep edilmiş; öte yandan, Adam Smith'in görüşüne dayanılarak zenginliğin kaynağının emek olduğu ve bu nedenle, emekçi, toprak sahibi ve kapitalist arasındaki haksız paylaşımın değiştirilmesi gerektiği sonucuna varımıştır (ENGELS/KAUTSKY, 1995: 252). İşçi sınıfı mücadelesinin ortaya çıkış aşamasına, hukuksal/siyasal yönün damgasını vuran bu görüşün karşısında, "sorunun hukuk alanında kalınarak çözülemeyeceğini savunan, bu nedenle hukuksal-siyasal alanı bir yana atarak buranın verimsiz olduğunu savunan ütopyacı sosyalistler" bulunmaktadir.

Engels/Kautsky hukuksal yaklaşımın temel bir kusuru bulunduğunu savunmaktadur. Buna göre, eşitlik, emek ürünlerine sahip olma gibi istekler, hukuksal olarak dile getirilince, ayrıntılı olarak hukuksal kalıplara dökülmeye çalışılınca, "içinden çıkılmaz çelişkiler içinde kaybolmakta"dır. Sorunun özüne, yani "üretim tarzının değişmesine hiç ya da yeterince değinilmemekte; konunan ve onun hukuksal ifadesinin dayandiğı tarihsel arka plan hesaba katılmamakta ve sadece hukuk duygusuna çă̆rnda bulunulmaktadır(ENGELS/KAUTSKY, 1995: 252)." 
Engels ve Kautsky tarafindan kaleme alınan bu makale, siyasal kalem kavgası amacımı taşımaktadır. Sosyalizmi hukukileştirme, bir haklar kataloğu olarak ifade etme girişimine bir yanuttır. Prof. Dr. Anton Menger'in, sosyalizmi, hukuk felscfesi açsından ele alıp, "bir iki kssa formüle, insan haklarının 19. yüzyıl için geçerli yeni basısından ibaret 'sosyalist temel haklar'a indirmeye çalışmasi" eleştirilmektedir. ${ }^{6}$ Anton Menger, sosyalizmin hukuken cle alını işlenmesini hukuk felsefesinin en önemli ödevi olarak görüyor ve sosyalizmi bir hukuk sistemi olarak açıklamak istiyordu.

Yukarıda uzun alıntılarla aktardığımız yazısıyla Engels/Kautsky, dinsel ve hukuksal dünya anlayışlarının feodalite ile kapitalizme ait olduğunu; iş̧̧i sınıfının dünyayı hukuk aracılığıyla kavrayıp anlamlandırmayacağını ve bu nedenle de yeni dünya anlayışının hukuk alanında inşa edilmeyeceğini açıkça ortaya koymuştur. ${ }^{7}$ Bu saptama, kapitalizm sonrası toplumsal yapıda yeni bir hukuk ortaya çıkıp çıkmayacağı sorunundan farklı bir bağlama atıf yapmaktadır. Yeni bir hukuk oluşacağı kabul edilse bile bundan yeni bir "hukuksal" dünya anlayışı doğmayacaktır.

Kanumca, Engels'in Marx'in ölümünden sonraya tarihlenen bu yazisıyla da özet olarak ortaya konduğu gibi, Marx ve Engels'in hukuk konusundaki temel tezi, hukuksal dünya anlayışınn eleştirisidir. Aşağıda, doğrudan veya dolaylı biçimde bu temel tez içinde yer aldığını düşündüğümüz sonuçlar, yine Marx ve Engels'in çalışmalarından yapılan alıntılarla aktarılmaya çalışılacaktır.

\section{B. Temel Tezden Türeyen Sonuçlar}

\section{Hukukun Kaynağı ve "ifade Etme" Sorunu}

Marx ve Engels'in yazılarında, hukukun kaynağı konusundaki değerlendirmeler de hukuksal dünya görüşünün eleştirisi amacıyla yapılan değerlendirmeler bağlamında yer almaktadır.

Marx'ın 1844 Felsefe Yaztlar'nda, hukuk, tikel bir üretim biçimi olarak tanımlanmakta, hukukun kaynağı da üretim alanına konmaktadır. Hukuk, genel üretim yasasına uyarak devinir ve gelişir. 1844 Felsefe Yazılari'nda ki değerlendirmeyle "hukuk, genel üretim yasasına uyan tikel bir üretim biçimi"dir. "Din, aile, devlet, hukuk, ahlak, bilim, sanat, vb., tikel üretim biçimlerinden başka bir şey değildirler ve genel üretim yasasina uyarlar (MARX, 1986: 191)."

6 Bu haklar, emeğin hasılasının tümü üzerindeki hak; varolma hakkı ve çalışma hakkıdır. "Hukukçular Sosyalizmi" yazısının tümünün Türkçe çevirisi için (MARX/ENGELS, 1977:170)

7 Menger'in sosyalizmi hukuk alanında kurma çabasına ilişkin yukarıda aktardığımız eleştirilere ek olarak Engels/Kautsky'nin şu saptaması da aktarılabilir: "Dę̆il mi ki bu temel haklar, sosyal gelişmeyi belirlemiyor oe gerçekleştirmiyor, tersine sosyal gelişme tarafindan belirleniyor ve gerçekleştiriliyor, o halde koca sosyalizmi temel haklara indirgemek için bu çaba niye?", (MARX/ENGELS, 1977: 177). 
Marx'in, Hegel 'in Hukuk Felsefesinin Eleştirisi'ndcki (1843) aile, burjuva sivil toplum ve devlet arasındaki ilişkilere yönclik saptamaları, "devlet" terimi " $h u k u k$ " olarak okunarak, hukuk konusuna da taşınabilir: "... aile ve burjuva-sivil toplum, ... devlet in varoluş biçimlerini oluşturur; devleti yapan aile ve burjuva sivil toplumun ta kendisidir. Onlar etkin öğeyi oluşturur. Buna karşıllk Hegel'de, onlar gerçek Idea tarafindan yaptlir. Onlar birleştiren ve onlardan bir devlet yaratan onlarn kendi öz yaşamlarını evrimi değildir, tersine onlar Ideanın içinden çıaran Ideanın yaşam sürecidir... [Aslinda] doğal aile temeli ve yapay burjuva sivil toplum temeli olmadan, siyasal devlet olamaz; bunlar onun için bir conditio sine qua non'durlar; ama Hegel'de koşul kendi tersine, koşullanana dönüşür; belirleyen öğe belirlenen öğe olarak koyulur... (s.17). Hegel devletten hareket ediyor ve insanı devletin bir öznelleşmesi olarak düşünüyor. Demokrasi insandan hareket ediyor ve devleti insanın nesnelleşmesi olarak düşünüyor. ... Insanın varoluş nedeni yasa değil ama yasanın varoluş nedeni insandır (MARX, 1997/47)."

Marx, hukukun, üretim biçiminden kaynaklanan toplumsal ihtiyaçları ifade ettiği yönündeki değerlendirmesini, Meclisi ve vergi yasaların eleştirdikleri için yargılandıkları, Ren Bölgesi Demokratlar Komitesi Davası'nda (1849) savunmasının temeli yapmıştır. Savcının savlarını, hukuk tekniği çerçevesinde de yantlayan Marx, bunun yanısıra siyasal gelişmelerin derinlemesine bir çözümlemesini yapmakta, vardığı sonuçları hukukun niteliğine ilişkin görüşleriyle birleştirerck, yasaların geçerliliğini de sorgulamaktadir. ${ }^{8}$

"Toplum hukuk üzerine kurulmaz, bu bir hukuksal yapintzdır. Tersine, hukuk, topluma dayanmall; kişisel kaprislerinden farkl olarak, toplumun, belirli bir zamanda egemen olan maddi üretim biçiminden doğan ortak çıkarlann ve gereksinimlerini ifade etmelidir (MARX, 1849)." Marx'ın bu temel kuramsal yarg1sı, o dönemde, toplumda saptadığı temel karşıtlığa, feodal düzenin kalıntısı olan büyük toprak sahipleri ile modern sanayiye dayanan burjuvazi arasındaki karşıtlığa gönderme yapmaktadır. Marx, fcodal düzenin kalıntısı büyük toprak sahiplerinden oluşan Birleşik Bölgesel Diyet'in, yeni toplumun gelişimini engelleyici ve sınrlayıcı yasalar koymasının meşruiyetini sorgulamaktadır.

Marx, savunmasinda Kod Napolyon'u (Fransiz Medeni Kanunu'nu) örnek vermcktedir: "Elimde tutmakta olduğum bu Kod Napolyon, modern burjuva toplumunu yaratmamıştır. Tersine, 18. yüzyılda doğan ve 19. yüzyılda gelişen burjuva toplumu, hukuksal ifadesini bu Kodda bulmaktadır yalnızca. Bu toplumsal koşullara uygunluğu sona erer ermez bu Kod basit bir kağıt parçasıma dönüşür." Yeni toplumsal

8 Savunma tekniğine ilişkin önemli sonuçlar çıkarılabilecek bu savunmasında, teknik hukuksal değerlendirmeleri ile siyasal/kuramsal çözümlemeleri arasındaki kesin bir sınır yoktur. Savunma bu açıdan ayrı bölümlere de ayrılmamaktadır. Bütünleşik bir metindir. Teknik hukukçuluk ile eleştirel hukukçuluğun birlikteliğine ilişkin önemli bir örnek sözkonusudur. 
koşullara uymayan yasaların basit bir kağıt parçasına dönüşmesinin Marx'ın söz ettiği kadar anlık bir kesintiyle gerçekleşmeyeceği açıktır. Toplumsal koşullara uygunluğu sonra eren yasalar, yeni yasalarla değiştirilinceye kadar bir süre daha devlet gücünün desteğini almaya ve zor da olsa uygulanmaya devam eder. Marx'ın anlatım biçiminin yarattığı, "bir anda" gerçekleşme zannını bir yana bıraktı̆̆ımızda, toplumsal gerçeklik ile hukuksal gerçeklik arasındaki uyumun bozulmasının, hukuk kurallarının yürürlüğüne etkisi olmasa da bir meşruluk ve uygulanabilirlik sorunu doğuracağına dikkat çckilmesi önemlidir. ${ }^{9}$

Belirli üretim biçimlerine özgü bulunan tarihsel hakllliklar ile bundan kaynaklan toplumsal ilişkilerin ifadesi olan hukuk arasındaki uygunluk geçicidir: "Eski yasalar, yeni toplumsal gelişmenin temeli yapılamaz. Bu yasalar, eski toplumsal koşullar tarafindan yaratılmıştır ve bunlarla birlikte ortadan kalkmalıdır. Yaşamin değişen koşullarıyla değişmeye mecburdurlar. Yeni toplumsal ihtiyaçlar ve talepler karşısında eski yasaları savunmak, esasen, toplumun güncel yaran karşısında, bir azınlı̆̆ın günü geçmiş özel çıkarlarnna ikiyüzlü biçimde, arka çıkmayla aynı şeydir (MARX, 1849)." Yeni üretim biçiminden köken alan üretim ilişkilerinin doğurduğu yeni toplumsal ihtiyaçlarla, bunların ifadesi olması gereken hukuk arasındaki uyumsuzluk, eski sınıflar tarafından, varolan hukuksal yapıya ısrarla dayanılarak sürdürülmeye çalışıllırsa, birçok teknik hukuksal sorunun ötesinde, köklü siyasal krizler de doğuracaktır. "Yeni toplumsal ihtiyaçlar ve talepler karşısında eski hukuksal temeli savunmak, varolan ihtiyaçlarla sürekli bir çelişki içindedir, ticaret ve sanayie engel olur, siyasal devrimlerle ortaya çıkan toplumsal krizlere yol açar ... (MARX, 1849)."

Hukukun, üretim biçiminden köken aldığı, Ekonomi Politiğin Eleştirisine Giriş'te de (1857) açık biçimde belirtilmiştir: "Her üretim biçimi, kendine özgü hukuksal kurumlarint; kendi yönetim tipini vb. yaratır (MARX, 1998: 452; MARX, 1993: 225)."

Marx'ın buradaki saptaması da yine doğrudan hukuka, hukukun yöntemine, kaynaklarına vb.lerine yönelik bir değerlendirme yapma amacından çıkmamaktadır. Marx bu saptamayı, kapitalist üretim biçimini, mülkiyet ve mülkiyeti güvenceye alan yapıları evrensel ve değişmez biçimiyle tanımlayarak tarih dışına çıkarma, evrenselleştirip ebedileştirme çabalarına karşı yapmaktadır.

Marx'ın buradaki savın özetlersck: "Her üretim, belirli bir toplum tipinin çerçevesi içinde ve onun aracillğıyla birey tarafindan doğanın mülk edinilmesidir." Bu anlamda, mülkiyetin üretimin koşulu olduğunu söylemck eşsözdür. Ama

9 Engels'e göre Marx, tarihsel üretim biçimine uygun tarihsel meşrulukları tanımaktadır: "Marx'in teorik çalı̧malarında, her zaman yalnızca belirli bir toplumun ekonomik koşulların yansıtmakla kalan hukuk, salt ikinci derecede, arka planda gözönüne almır. Buna karşllık, ön planda, belirli dönemler için, belirli durumlara ve belirli mülk edinme biçimlerine özgü bulunan ... 'tarihsel hakklilıklar', 'tarihsel meşruluklar' gözönünde tutulur.", (MARX/ENGELS, 1977: 175). 
bundan geçmiş mülkiyet biçimlerini gözardı ederek "özel mülkiyetin" üretimin tek koşulu olduğu sonucuna varmak kabalıktır. Ayn özellik hukuk için de geçerlidir. "Her üretim biçimi kendine özgü hukuksal kurumlarını yaratır." Bu nedenle örneğin "Faustrecht (en güçlünün hukuku) da bir hukuktur ve bu hukuk, 'hukuk devleti'nde başka bir biçim altında varlığın sürdürür (MARX, 1998: 452; MARX, 1993: 225)."

Marx, Ekonomi Politiğin Eleştirisi'ne Katkinn (1859) Önsözünde, "uzmanlaşmıs çalışmalarımın konusunun, felsefe ve tarih yanında ikincil bir bilgi kolu saymıs olmasına karşın hukuk" olduğunu ve kafasında biriken kuşkuları gidermek için de ilk olarak Hegelci Hukuk Felsefesini eleştirici bir gözle ele aldığın belirttikten sonra Hegelci hukuk felsefesinin eleştirisinde vardığı sonucu aktarmaktadır. Değerlendirmesi, bir Marksist hukuk yaklaşımından söz edilebilecekse bunun temelini oluşturabilecek niteliktedir: "Araştırmalarım devlet biçimleri kadar hukuki ilişkilerin de ne kendilerinden ne de iddia edildiği gibi insan zihninin genel evriminden anlaşılamayacağı, tam tersine, bu ilişkilerin kökenlerinin Hegel' in Ö 'sivil toplum' adı altında topladı̆̆ı maddi varlık koşullarnda bulunduklan ve sivil toplumun anatomisinin de ekonomi politĭ̆in içinde aranmast gerektĭ̆ $i$ sonucuna ulaştı." Marx ekonomi politik konusundaki incelemelerinde vardığı sonucu da şu şekilde ortaya koymaktadır: "Genel sonuç kısaca şöyle formüle edilebilir: Varliklarının toplumsal üretiminde insanlar aralarında zorunlu, kendi iradelerine bağlı olmayan belirli ilişkiler kurarlar; bu üretim ilişkileri, onların maddi üretici güçlerinin belirli bir gelişme derecesine tekabül eder. Bu üretim ilişkilerinin tümü, toplumun üretim yapısın, belirli toplumsal bilinç biçimlerine tekabül eden bir hukuki ve siyasal üstyapının üzerinde yükseldiği somut temeli oluşturur (MARX, 1993: 22)."

Marx'ın bu temel saptamalarına göre, hukuk, üretim ilişkilerine, yani insanların varlıklarının temcl üretiminde kurdukları zorunlu, gayriiradi ilişkilere göre üstyapıyı oluşturur. Bu üstyapıya da "belirli toplumsal biliņ̧ biçimleri" tekabül eder. Demek ki Marx'a göre, hukuk, aynu zamanda bir "bilinç biçimi"dir. Marx, hukuksal bilinç biçimi ile maddi hayat arasındaki ilişkinin yönünü de açıkça ortaya koymaktadır. "Insanların varlığını belirleyen şey bilinçleri değildir; tam tersine, onlarnn bilincini belirleyen toplumsal varlıklaridır."

Hukuksal üstyapı, üretim ilişkileri üzerinde nasıl "yükselir"? İkisi arasında nasıl bir belirlenim ilişkisi vardır?

Yine Ekonomi Politiğin Eleştirisine Katki'nun (1859) Önsözünde Marx'ın, üretici güçlerin gelişimi ile üretim ilişkileri arasındaki çelişkiyle ortaya çkan "toplumsal devrim çă̆ı"na ilişkin değerlendirmelerinde bu soruya ilişkin ipuçları bulunabilir: "Gelişmelerinin belli bir aşamasında, toplumun maddi üretici gü̧̧leri, o zamana kadar içinde hareket ettikleri mevcut üretim ilişkilerine ya da bunlarm hukuki ifadesinden başka birşey olmayan, mülkiyet ilişkilerine ters düşer. Üretici güçlerin gelişmesinin biçimleri olan bu ilişkiler, onların engelleri haline gelir (MARX, 1993: 23)." 
Bu saptamadaki temel yargları şu biçimde sıralayabiliriz:

1. Üretim ilişkileri, üretici güçlerin içinde harcket ettikleri biçimlerdir.

2. Hukuk bu ilişkilerin (biçimlerin) ifadesidir.

3. Kanımca "ifade" ilişkisi, tek yanlı bir yansıtma değildir. Zira, üretim ilişkilerinin, üretici güçlerin gelişimine uyumu otomatik değildir. "Toplumsal devrim çă̆ı"nın başlaması da bu nedenledir. "Iktisadi temeldeki değişme, tüm üstyapının eninde sonunda dönüşümüne yol açar." Ancak bu dönüşüm otomatik ve eşanlı değildir. Bu nedenle de hukuksal üstyapının üretim ilişkilerini yansıtmasından değil de "ifade etmesin"den söz etmek gerekir.

4. Marx'in saptamalarında şöyle bir ilişkilendirme görülmektedir: Toplumun maddi üretici güçleri; bu üretici güçlerin, içinde hareket ettikleri ve bunlarla uyumlu olması gereken üretim ilişkileri ve bu ilişkilerin ifadesi olan hukuksal üstyapı (biçim).

Marx'ın devam eden değerlendirmelerinden hukukun "idcolojik biçim" olarak nitelendirildiğini de görüyoruz. "Iktisadi temeldeki değişme, kocaman üstyaptyı, büyük ya da az bir hızla altüst eder. Bu gibi altüst oluşların incelenmesinde, daima, iktisadi üretim koşullarının maddi altüst oluşu ile-ki, bilimsel bakımdan kesin olarak saptanabilir-, hukuki, siyasal, dinsel, artistik ya da felsefi biçimleri, kısaca, insanların bu çatışmanın bilincine vardıkları ve onu sonuna kadar götürdükleri ideolojik şekilleri ayırdetmek gerekir (MARX, 1993: 23)."

Hukuk, aynı zamanda, insanların maddi üretim alanında, üretici güçler ile üretim ilişkileri arasındaki çatışmanın bilincine vardıkları ideolojik bilinç biçimlerinden biridir. Bu nedenle de böylesi altüst oluş dönemlerini değerlendirmede kullanılamaz. Hukukun ve benzeri ideolojik bilinç biçimlerinin, dünyayı anlamadaki özsel zaafını Marx şöyle açıklamaktadır: "Nasıl ki, bir kimse hakkında, kendisi için taşıdı̆̆ fikre dayanilarak bir hüküm verilemezse, böylesi bir altüst oluş dönemi hakkında da bu dönemin kendi kendini değerlendirmesi gözönünde tutularak bir hükme varlamaz.; tam tersine bu değerlendirmeleri maddi hayatın çelişkileriyle, toplumsal üretici güçler ile üretim ilişkileri arasındaki çatışmayla açıklamak gerekir (MARX, 1993: 23-24)."

Insanların çatışmaların bilincine vardıkları ideolojik biçimlerden biri olan hukuktan yola çıkarak maddi dünyayı açıklamak mümkün değildir. Tersine hukuksal "ifadeleri", "değerlendirmeleri" maddi hayatın çelişkileriyle, üretici güçlerle üretim ilişkileri arasındaki çatışma ile açlklamak gerekir. Hukuku gerçekten açıklayabilip anlayabilmek için, hukukçular tarafından "hukuk ötesi" olarak nitelenen alana girmek bir zorunluluktur.

Marx, Proudhon'a yönclik eleştirilerini içeren, J-B Schweitzer'e Mektubu'nda da (1865), mülkiyetin hukukla anlaşılamayacağını söylerken, hukukun üretim ilişkilerinin ifadesi olduğu saptamasını yapmaktadır: 
"Mülkiyetin ne olduğu sorusuna, mülkiyet ili̧̧kilerini, irade ilişkilerinin hukuki ifadesinde değil fakat gerçek biçiminde yani üretim ilişkilerinde kavrayan bir eleştirel siyasal iktisat çözümlemesiyle yant verilebilir." ${ }^{10}$ Buna göre, mülkiyet ilişkilerinin, daha genel ifadeyle iktisadi ilişkilerin bir de hukuki ifadesi bulunmaktadır. Hukuk kendi dışında yer alan bir gerçekliği "ifade" etmektedir.

Yukarıda da belirttiğimiz gibi Marksizmin hukuk konusunu ele alı̧ nedeni, genel metodolojik/epistemolojik kaygısıdır. Dünyaya ilişkin bilgi hukuksal bilgi değildir zira, hukukun kendisi bir "ifade"dir, bir dolayımdır. Bu nedenle hukuk tarafından ifade edilen fenomenlerin gerçek temellerinin araştırılması gerekir. Marksistlerin bulduğu gerçek temel, "gerçek biçim", "üretim iliskileri"dir.

Üretim ilişkilerinin, hukuk alanında yeniden kurulmasına, bir de hukuk olarak ifade edilmesine neden gerek duyulur? Engels, Ludwig Feuerbach Klasik Alman Felsefesinin Sonu'nunda (1886) hukuk ile iktisat bağlantısın kurarken bu soruya dolaylı bir yant vermektedir: "Devlet ve kamu hukuku iktisadi ilişkilerle belirlendiği gibi, gerçekte, verili koşullarda normal sayılan bireyler arası ilişkileri yaptırıma bă̆layan özel hukuk da elbette ikt isadi ilişkilerle belirlenir."11

Engels'in saptamasıyla, özel hukuk bireyler arası normal iktisadi ilişkileri yaptırama bağlar (düzenler). Hukukun (özel hukukun) işlevi normal iktisadi koşulların işleyişini yaptırıma bağlamak ve düzenlemek, yani güvenceye almaktır. Hukukun, bu toplumsal işlevi yerine getirebilmesi için tüm iktisadi ilişkileri, bir de hukuk diline çevirmesi gerekir. Yani hukukun terimleriyle "ifade" etmesi gerekir. Böylelikle dünyanın, hukuksal kavramlarla hukuk alanunda bir kez daha kurulduğu görülür. Engels'in anlatımıyla "her özel durumda ekonomik olgular, hukuksal yaptırımdan yararlanmak için hukuksal biçim kazanmak zorundadir (ENGELS, 1992: 52)." Hukuk, (bireylerarası) iktisadi ilişkileri yaptrıma bağlama işlevini gerçekleştirmek için, bu gerçekliği, hukukun kavramları, kategorileri, ilkeleri ve kurallarıyla "hukuksal bir gerçeklik" olarak yeniden kurar.

Hukukun, sadece bir yansı olmadığı, sabit oturmuş, binlerce profesyonel hukukçunun, mahkemelerin, polisin, devletin faaliyetiyle oluşan bir gerçekliğinin olduğu da açıktır.

Hukuk bir gerçekliğin ifadesi, bir başka alanda yeniden kurulmasıdır. Bu ifade ilişkisinin nasıl işlediği araştırılmalıdır. Gerçekliğin hukuk alanındaki ifadesi, ifade edilen gerçeklikle bağlanı belirli oranda koparmış yeni bir

10 Marx saptamasına devam ediyor: "Proudhon, tüm bu iktisadi ilişkileri hukuksal mülkiyet kavramina entegre ettiğinden, Brissot'nun henüz 1789'dan önce vermiş olduğu yanitın ötesine gidememiştir: 'mülkiyet hirsızlıktır."', (MARX, 1995: 176-184).

11 Engels, ayn yerde, hukukun iktisadi ilişkiler tarafından belirlenmesi "biçiminin" farklı olabileceğini Anglosakson ve Roma hukuk sistemlerini örnek göstererek açıklamaktadır (ENGELS, 1992: 52). 
gerçekliktir. Yeni bir gerçeklik haline gelmiş hukuk alanında hayat, gerçeklikten köken almış kavram, kategori, ilke ve kurallarla kendine özgü bir şekilde devinir. Işleyiş anında, hukuksal kavramların/kuralların, her seferinde yeniden ifadesi oldukları gerçeklikle sinanmaları gerekmez. Bunun dışında, iç çelişkilerinden arınması ve düzenli işleyişinin sağlanması için hukuk, birçok varsayımlarla pekiştirilmiştir. Bu anlamda hukuk, işleyişi sırasında gerçekliğe büyük oranda kapılarını kapar. Elbette hukuk bir gerçekliği, üretimin biçiminin damgasinı vurduğu toplumsal ilişkileri düzenlemektedir ancak, hukukun işleyişinde önemli olan bu ilişkilerin hukuksal soyutlamalara uyup uymadığı, bunların kendi alanı kapsamına girip girmediğidir. Gerçeklik, hukuksal soyutlamaların kapsamına girdiği oranda, "hukuksal gerçckliğin" konusu olur. Hukuk, ondan köken almasına karşın kavramlarıyla açılayamadığı oranda gerçckliği yok sayar; onu hukukta bir etken olarak kabul etmez.

Engels, Conrad Schmidt'e Mektubunda (1890) hukukun, "ifade etme" işlevindeki, göreli özerkliği, yani kendisini yaratan gerçekliğin yanısıra, o temele bağımlı ve duyarlı olmayı sürdürse de, ayrı bir "hukuksal gerçeklik" yaratması hakkunda önemli değerlendirmeler yapmaktadır. "Profesyonel hukukçuları yaratan işbölümü gerekli hale geldiğinde, üretim ve ticarete genel bağhlĭğı olan ve aynt zamanda bu alanlar üzerinde etkide bulunma yeteneğini sürdüren yeni bir alan [hukuk] açıllir. Modern devlette hukuk sadece, genel ekonomik duruma uyup onun ifadesi olmakla kalamaz fakat aynı zamanda kendi içinde tutarl bir ifade olmak ve kendi iç çelişkileri nedeniyle gözebatar derece tutarsız olmamak zorundadır. Bunu gerçekleştirmek için, iktisadi koşullarn yansttllmast git gide bozulur. O kadar ki, mevzuu hukukun bir sinifin egemenliğini, saf, kesin ve tüm ağırliğtyla ifade etmesine (-ki bizzat bu durum "adalet kavramina" aykındır) nadiren rastlanır (ENGELS, 1996: 233)." Engels'in açıkça ortaya koyduğu gibi, Marksizm'de hukukun ifade etme işlevi mekanik bir aktarma/yansitma olarak anlaşılmamakta; belirli oranda bağımsızlaşmış hukuksal gerçekliğin varlığı da kabul edilmektedir. Hukuksal gerçeklik de özerk biçimde devinmektedir. Engels' göre, "hukukun gelişim' seyri, büyük ölçüde şöyledir: iktisadi ilişkilerin, hukuksal ilkelere doğrudan çevrilmesinden doğan çelişkiler giderilmeye ve uyumlu bir hukuk sistemi yaratılmaya çalışılır; ardindan, daha sonraki iktisadi gelişmenin etkisi ve baskısıyla hukukun, i̧̧ çelişkiler yaratan, sürekli ihlaliyle karşılaşılır." Hukuk, hem bir sistem olması nedeniyle iç̧̧lişkilerini sürekli gidermeye uğraşır hem de üretim ilişkilcrindeki değişimi hukuk içinde ifade etmeye. Bu hukukta, sürekli gerilimler doğuran yapısal bir çelişkidir.

Engels, Conrad Schmidt'e Mektubunda (1890), hukukun ve meslekten hukukçuların durumunu, iktisat bilimi ve meslckten iktisatçlarla karşlaş̧ırmaktadır. Zürih Post Gazetesinin editörlüğü görevini üstlenen Conrad Schmidt'e, para ve spekülasyon piyasasının canlı olduğu bu kentte ekonomi hakkında çok şeyler öğrencbileceğini, uygulamaya ilişkin bilgilere sahip olabileceğini söylüyor. Ancak bir uyarıda da bulunuyor Engels: "Iktisadi, siyasal 
ve dĭger yansımalar, insan gözündekiler gibidir, gözdeki mercekten geçtiklerinde başaşağı olurlar. Bu benzerlikte, sadece, bunların tekrar ayakları üzerine koyacak olan sinir sistemi eksiktir." Engels bu mektubunda söz etmemekle birlikte, "Hukukçular Sosyalizmi" yazısını incelerken gördüğümüz gibi, başaşağı duran iktisadi, siyasal ve diğer yansımaları düzeltecek sinir sisteminin tarihsel maddecilik olduğunu savunmaktadır. Hukuk da gerçekliği başaşağı yansıtan "diğer yansımalar"dan biridir. Engels'in burada yaptığı değerlendirme, hem hukukun "ifade olma" niteliğinin gerçek etkisi hem de genel olarak ideolojinin gerçeklik üzerindeki etkisi konusunda çok önemlidir. "Iktisadi ilişkilerin hukuk ilkeleri olarak yansıması da zorunlu olarak başaşağıdır; bu durum hukuk alanında faaliyette bulunan kişiler farkında olmadan gerçekleşir; bunlar sadece iktisadi yansımalar olsa da hukukçu a priori ilkelere göre iş yaptığını santr; herşey tepetaklaktır. Kanımca, farkına varılmadı̆̆ı sürece, ideolojik kavrayıs dediğimiz şeyi oluşturan bu tersine çevrilme, iktisadi temel üzerinde etkide bulunur ve belirli sintrlar içinde onu değiştirebilir de (ENGELS, 1890)."

Ideolojik kavrayışın, iktisadi temel üzcrinde belirli sınırlar içinde de olsa etkide bulunabileceği Engels tarafından kabul edilmektedir. Bu etkinin yönünü, Engels'in, iktisadi gelişme üzerinde devlet iktidarının etkisine ilişkin değerlendirmelerinden çıarabiliriz: "devlet iktidarnnın, iktisadi gelişmeyle tepkimesi üç biçimde olabilir: iktisadi gelişme ile aynt yönde olur ve bu durumda gelişme daha hızlanır; gelişme çizgisine ters düşebilir, uzun erimde devlet parçalanır; veya iktisadi gelişmeyi belirli gelişim yollarından ayırarak ona başka gelişim yönlerini zorla kabul ettirir. Bu son durum, öncekilerden birisiyle sonuçlantr. Ikinci ve üçüncü durumlarda, siyasal iktidarm iktisadi gelişmeye büyük zarar verebileceği, büyük miktarlarda enerji kaybıyla ve maddi kayıpla sonuçlanacă̆ı da açıktır (ENGELS, 1890)."

Engels, Ailenin Özel Mülkiyetin ve Devletin Kökeni'nde (1884), evlenme sözleşmesi ile iş sözleşmesine ilişkin değerlendirmeleri vesilesiyle bu noktaya dikkat çekmektedir. "[Evlilik sözleşmesi gibi] iş sözleşmesi de taraflar arasında özgürce yapılmış sayılır. Ama bu özgürlük, taraflar arasındaki eşitliğin, yasa tarafindan kağıt üzerinde kurulmasına dayanır. Sinıfsal konumlar arasındaki farkın taraflardan birine verdiği güç, bu güçlü tarafin diğeri üzerindeki baskısı-iki tarafin gerçek iktisadi durumu-bütün bunlar yasayı hiç ilgilendirmez. ... Gerçek yaşamın oynandiğl hukuk kulislerinin ardında olup bitenler ve bu özgür onamanın ne biçimde sağlandığı yasayı da hukukçuyu da hiç ilgilendirmez (ENGELS, 1990:77)."

Engels'in bu değerlendirmeleri de bizzat "hukukun eleştirisi" niteliğinde değildir. Yukarıda da belirttiğim gibi, dünyanın hukukçu bakış açısıyla kavranamayacağı açıklanmaya çalışılmaktadır. Ayrıca buna, hukuki eşitlik arayışlarıyla yetinen siyasal akımların eleştirisi de eklenmektedir. Ancak bizzat hukuka yönelik bir eleştiri bulunmamaktadır.

Engels'in adlandırmasıyla "hukuk kulisleri", hukukçuların sevdikleri adlandırmayla "hukuk ötesi" ile hukuk arasındaki, hukukçuların sorgulamaksı- 
zin kabul ettikleri kopukluk, yapisal bir zorunluktur. Marx ve Engels tarafindan hukuksal dünya görüşünün reddedilmesinin gerekçesi de bu zorunlu kopukluluktur. Hukukun bu niteliği, gerçekliğin hor zaman için eksik ve çarpıtılmış bir ifadesine yol açacaktır. Kurallarla toplumsal ilişkileri düzenleyen bir sistemin zorunlu olarak soyutlamalara dayanması gerekir. Nitekim common law geleneği, dışsal bir otorite tarafından (devlet/yasakoyucu) konmuş genel, soyut kurallara, yani kanunlara daha sınırlı yer vermesine karşılık, mahkeme kararları da somut olayları aşan ve gelecekteki benzer durumlara uygulanmasına olanak sağlayan kuralsallı̆ga sahiptir. Hukuk kuralı bir soyutlamadır. Gerçekliğin kurala uyup uymadığına bakılır. Uygunluk yoksa, gerçeklik ya kapsam dışı sayılır ya da istisnalarla, yorumlarla kural yumuşatılır veya değiştirilir. Hukukun gerçekliğe kapılarını tam olarak kapattığı da söylenemez. Engels'in verdiği örnckte, yaşamak için cmekgücünü satmaktan başka olanağı bulunmayan birinin iş akdi yaparken özgür olduğunu düşünmek safdillik olur. Ancak, hukukun, bu temel sinifsal konuma duyarsiz olmasina karşın, kendi tanımladiğı "irade serbestisi"nin, sözleşmenin kurulması anında gerçekleşip gerçekleşmediğini araştıracak (hata, hile, ikrah, hak ve işlem ehliyeti gibi) araçlar geliştirdiği de malûmdur.

Gerçeklik ile hukuksal gerçeklik arasındaki ilişkinin, hukukçular tarafindan tam bir kopukluk olarak algilanmasının ve aslında hukukun ifadesi olduğu gerçekliğin "hukuk ötesi" olarak nitelenmesinin önemli nedenlerinden biri de hukukun ayn zamanda işbölümü sonucunda özcrk bir iş haline gelmiş olmasıdır. Marx ve Engels, Alman Ideolojisi'nde (1845) işbölümünün, gerçekliği anlamada yarattığı bozulmaya değinmektedir: "Işbölümü nedeniyle o işin özerkliğe ulaşması sonucunda herkes kendi işine gerçek gözüyle bakar. Zanaatlan ile gerçek arasındaki bağ konusunda, zorunlu olarak, zaten mesleğin kendi doğasının gerektirdiği kadar hayaller kurarlar. Hukukta, siyasette vb., bu ilişkiler -bilinçte kavrantrlar; bu kişiler, bu kavramların üstüne çıkamadıklarnndan, bu ilişkiler konusunda sahip olduklan kavramlar, onlann kafalannda sabit kavramlardır: sözgelimi yargı६, yasalarn uygular ve bunun için de mevzuatı gerçek etkin devindirici olarak kabul eder (MARX/ENGELS, 1992: 110)."

Marx, birbirleriyle örtüşmeleri herzaman için mümkün olmayan, hukuksal varoluş ile gerçek varoluş (l'existence réelle) arasında bir ayrım yapmaktadır. Bu ayrımı, 18 Brumaire'de (1851), Fransız 1848 Anayasası'ndaki özgürlüklere, bunların uygulanmasına ve bu Anayasanın niteliğine ilişkin değerlendirmelerinde bulabiliriz. Marx'ın değerlendirmesine göre, 1848 Anayasası'nı kurduğu haklar sistemi hem hakları savunanların hem de hakların kısıtlanmasın 1 isteyenlerin isteklerini gerçekleştircbilecck niteliktedir. "Anayasanın her paragrafı kendi karş-savinı da içermektedir." "Bir yandan temel özgürlükler tantnmakta, Fransiz halkmin mutlak hakk ilan edilmekte, öte yandan bunların ancak başkasının eşit haklart, kamu güvenliği ve bu hakları düzenleyen yasalarla çatışmadıklan sürece sınırsız olduklan belirtilmektedir. Böylece, anayasanın 
buyruklarına uygun olarak bu mutlak özgürlükleri, kamu güvenliği 'yani burjuvazinin güvenlĭgi' yararına, burjuvazi dışındaki simıflara yasaklamak veya polis tuzaklarından başka birşey olmayan koşullara bağlamak mümkündür." Bunun içindir ki, "özgürlük sözüne saygi gösterildiği ama onun gerçekleşmesi yasaklandı̆̆ı sürece, özgürlüğün gerçek varoluşu tamamen yok edilmiş olsa bile anayasal [yani hukuksall varoluşu dokunulmamıs olarak kalmıştır (MARX, 1990:31)."

Marx'ın, anayasa hukuku alanında da önemli vurguları bulunan bu değerlendirmesinden, konumuz açısından önemli bir yargıya varılabilir. Marx, hukukun, ifadesi olduğu gerçek yaşam dışında da bir gerçekliği olduğunu kabul etmektedir. Ancak, hukuksal varoluş ile gerçek varoluş arasındaki ilişki sorunludur. Bu sorun, hukukçuların geleneksel yakınma konularından biri olan "kanunların, kuralların uygulanmıyor olması" şikayetinden farklıdır. Sorun uygulanmama sorunu değildir. Bir uygulamama keyfiliğinden de kaynaklanmaz. llk olarak, hukukun doğası ve işlevi gereği toplumsallı̆̆ aynen aktarmayacağı/ yansıtmayacağı/ifade etmeyeceği açıktır. İkincisi, hukuk çoğu zaman bir kuralın birden fazla anlamlandırılmasına olanak sağlayan bir iç yapıya sahiptir. Marx'ın aktardığımız değerlendirmesinde de görüldüğü gibi, örneğin anayasanın hak ve özgürlüklere ilişkin hukuki düzeneği hem "özgürlükleri ortadan kaldıranlar" hem de "bu özgürlükleri eksiksiz isteyen demokratlar" tarafından kullanılabilmektedir. Bu özellikten hukukun bir kandırmaca olduğu sonucuna varılamaz. Daha doğru bir değerlendirme hukukun her iki yan için de bir olanak olduğudur. Hukuk kendi iç tutarlı bozulmadığı sürece değişik sonuçlara olanak sağlayacak olası yorumları bünyesinde barındırır.

\section{2. İnceleme Yöntemi}

Daha önce de vurguladığımız gibi, dünyayı açıklamanın aracı olarak hukukun kullanılamayacağı, Marksizmin hukuk konusundaki temel savıdır. Bu sav ikili bir anlam taşır. llk olarak, dünyayı algılama, inceleme ve anlama yöntemi konusunda, hukukun bu iş için elverişli olmadığını belirterek önemli ipucu vermektedir. İkinci olarak, hukukun nasıl incelenmesi gerektiğine ilişkin temel bir yöntemsel ilke ortaya çıkarmaktadır. Hukukun kaynağına ilişkin olarak önceki bölümde aktardığımız değerlendirmeler, gerçekte hukukun incelenme yöntemine ilişkin bilgiler de vermektedir.

Hukuksal kurumların nasıl incelenmesi gerektiğine ilişkin Marksizmin verdiği tipik örnek mülkiyettir. "Mülkiyct" kurumunun ne olduğunu anlayabilmemiz için hukuksal yönünü incelemck yetcrli değildir. Marx'in J-B Schweitzer'e Mektubundaki (1865) saptamasıyla "mülkiyetin ne olduğu sorusuna, mülkiyet ilişkilerini, irade ilişkilerinin hukuki ifadesinde değil fakat gerçek biçiminde yani üretim ilişkilerinde kavrayan bir eleştirel siyasal iktisat çözümlemesiyle yantt verilebilir (MARX, 1995: 176)." 
Hukuktan kalkarak, hukuk alanı dışında bir gerçeklikten doğmuş ve işlemekte olan bir kurumu açıklamak mümkün olmadığına göre, hukuksal kurumlan sadece hukuk alan içinde kalarak açılamak, yani, hukuku hukukla açıklamak da mümkün değildir. Hukuksal kurumlara ve bir bütün olarak hukuka yönclik her türlü anlama çabası zorunlu olarak "hukuk ötesi"ne açılmak zorundadir.

Hukukun üretim biçiminden tam bir bağımsızlığı olmadığı gibi, tam bir bağımlılığı da sözkonusu değildir. Bu nedenle yasakoyucunun serbest iradesiyle kuralların; hukuk öznelerinin serbest iradesiyle de hukuksal ilişkilerin kurulduğu kısmi bir doğrudur. Bunun gibi, hukuk öznclerinin, hukuk kurallarınun ve bir bütün olarak da hukuk sisteminin üretim biçiminin bir yansıması olduğu da kısmi bir doğrudur. Bu nedenle, hukuk incelemelerinde kurucu iradeyi tek veya asıl veri kabul etmek yanlıştır. Tersinden, sadece üretim ilişkilerine vurgu yapılması da hatalıdır. En tehlikeli sonucu, hukukun tamamen verimsiz, anlamsız ve herhangi bir özgün varlı̆̆ olmayan bir gölge alan olarak nitelenmesidir.

Hukukun kaynağını devletin veya diğcr hukuk öznelerinin iradesinde arayan anlayışlar, Alman Ideolojisi'nde (1845) Marx/Engels tarafindan eleştirilmektedir: "Özel hukukta, varolan mülkiyet ilişkileri, genel iradenin sonucu olarak açıklanır. Bu hukuksal bir yanılsamadır. ... Hukukçuların bu yanılsaması, hem hukukçular için hem de tüm hukuk sistemi için, bireylerin kendi aralannda, örneğin sözleşmeyle doğan ilişkilerin saf bir olumsallık olarak görülmesini ve bu çeşitten ilişkilerin, isteğe bağh, içeriği tamamıyla sözleşmeyi yapanlarm keyfi kişisel iradelerine dayanan ilişkiler olarak kabul edilmesini de açıklar (MARX/ENGELS, 1992: 109)."

Marx/Engels'e göre, hukuk, kaynağını sadece "irade"den almaz; salt iradeye indirgenemez. Hukuk alanındaki ilişkiler ve işlemler hukuk öznelerinin iradeleriyle kurulur ancak, hukukun, hukuk özneleri dışındaki kurucu kaynağını da araştırmak gerekir. Bu durum özel hukuk ilişkileri (sözleşme ilişkileri) için olduğu kadar, kuralkoyucu iktidar için de geçerlidir. "Devlet egemen bir sınıfın bireylerinin, onun aracılığıyla kendi ortak çıkarlarını üstün kıldıklan bir biçim, içinde bir çağın bütün sivil toplumunun özetlendiği bir biçim olduğundan, bunun sonucu olarak, bütün kamusal kurallar devlet aracliğ̆ından geçer ve siyasal bir biçim alırlar. Bu yüzden yasanin iradeye dayandiğ , hatta daha iyisi, özgür iradeye dayandiğı kuruntusu, somut temelinden kopmuş̧ur (MARX/ENGELS, 1992: 107)."

Marx ve Engels'ın yazılarında, hukukçu yaklaşımının eleştirisinin (yani dünyanın hukuksal kavramlar aracılığıyla doğru biçimde algılanabileceği yaklaşımınun eleştirisinin) ötesine geçilip hukukun nasıl incelenmesi gerektiğine ilişkin değerlendirmeler yapılmasına pek rastlanılmamaktadır. Az sayıdaki değerlendirmelerden biri ise Engels'in Anti-Dühring (1878) çalışmasındaki hukuka ilişkin bölümlerdir. Dühring'in hukuk konusundaki kurgusunu 
değerlendiren Engels bunu "gerçek temelinden kopmuş bir imaj" olarak nitelemektedir. Engels'e göre, Dühring'in hukuku kurgulama yöntemi yanlıştır. Doğru yöntem, "hukuku çevreleyen insanlarm, gerçek toplumsal ilişkilerinden" yola çıkmaktır. Engels bu noktayı derinleştirerek eleştirisini sürdürmektedir. Dühring "gerçek toplumsal ilişkilerden" yola çımak yerine, hukuku kurgularken "kavram"dan ("toplumun en yalın denilen öğelerinden") harcket etmiştir. Engels, kavramdan yola çıkarak hukuku açıklamaya çalıştığında Dühring'in hangi araçları kullanabileceğini de araştırmaktadır. Buna göre ilk araç, "temel olarak alınan soyutlamalarda hâlâ varlığını sürdürebilen zayıf gerçeklik kalıntılan"dır. Ikinci araç ise, Dühring'in "kendi bilincinden çıkararak kullandığı içerik'tir. Bilincinde ise, "içinde yaşadiğı toplumsal siyasal koşullarn dışavurumu olan hukuksal sezgiler, konu hakkında literatürden ödünç alınmıs fikirler ve nihayet kişisel fanteziler" yer alır. Somut tarihsel bağlam ve gerçeklikten uzaklaşılmaya çalışılsa da gerçeklik böylelikle tüm tahlillere sızar. Dühring tüm zamanlar ve herkes için geçerli bir hukuksal öğreti geliştirmek istemiştir ancak, gerck kavramlardaki/ soyutlamalardaki gerçeklik kalıntılarının ve gerekse de sezgilerinin, içinde yaşadığı toplumsal, siyasal koşulların dışavurumu olması Dühring'in "kapıdan atmak istediği tarihsel gerçekliğin bacadan girmesine" neden olmaktadır. Bunun sonucu olarak da ortaya, "kendi zamanının tutucu ve devrimci akımlarının, gerçek temelinden koptuğu için biçimsizleşmiş, içbükey bir aynada olduğu gibi başaşă̆ duran bir görünt üsünden başka birşey çıkmamıştır (ENGELS, 1995: 163)."

Hukukun, gerçek toplumsal ilişkilerden yola çımak yerine kavramlardan hareketle incelenmesi ve her dönem ve herkes için geçerli bir hukuk kavramının ortaya konmaya çalışılması durumunda ancak gerçckliğin tepe taklak olmuş bir görüntüsüne, yani hukuksal ideolojiye varılabilir.

\section{Hukukun Tarihselliği ve Geleceği}

Hukuk tarihin belirli bir aşamasında doğmuştur. Engels, Ailenin Özel Mülkiyetin ve Devletin Kökeni'nde (1884), hukuk olmayan bir kurallar düzeninden söz etmektedir. Engels'in, yabanıl halklarda bulunan grup halinde evlilik kurumuna ilişkin değerlendirmesinde böyle bir ayrıma rastlanmaktadır. "Kadın soy zincirinin ve ondan çıkan miras ilişkilerinin bu tekelci tanınışını, Bachofen 'analık hukuku' terimiyle belirtiyor; kısa olduğu için ben de bu deyimi kullanıyorum; ama bu uygun bir terim değildir, çünkü toplumun bu aşamasında, sözcüğün hukuksal anlamında 'hukuk' henüz sözkonusu edilemez (ENGELS, 1990: 47)."

Engels'e göre tarihin belli bir aşamasında, sözcügün hukuksal anlamında bir hukuk henüz doğmamıştır. Engels, "sözcüğün hukuksal anlaminda hukuk ('droit' au sens juridique du mot)" nitelemesini açmamıştır. Sözkonusu toplumsal gelişim aşamasındaki "kadın soy zinciri" bir toplumsal "kural"dır. Engels bu kuralın hukuksal olmadığın, zira bu dönemde henüz hukukun ortaya 
çıkmadığın belirtmektedir. Ancak bu kuralın niteliğine ilişkin yeni bir tanımlama da getirmemekte, "analık hukuku" tanımlamasını kullanmayı sürdüreceğini belirtmektedir. Buna göre hukuk, toplumsal ilişkileri düzenleyen kuralların bir türü olarak, belirli bir tarihsel aşamadan sonra ortaya çıkmıştır.

Marx ve Engels'in 1846 tarihli çalışmaları Alman Ideolojisi'nde (1845) hukukun kökenlerine ve kaynağına ilişkin değerlendirmeler bulunmaktadır. "Devletin ve hukukun mülkiyet ile ilişkileri" başlı̆g altında, "özel hukuk ve özel mülkiyet, doğal topluluğun çözülmesiyle doğmus ve birlikte gelişmiştir" saptaması yer almaktadır (MARX/ENGELS, 1992: 107).

Bu kısa saptamadan çıkan ilk sonuca göre, hukuk, üretim araçlarınun belli ellerde toplanmasıyla (sinffı toplumla) doğar. Sınıflı topluma geçiş, "hukuklu toplum"a geçiş anlamina da gelir.

Ikinci olarak, hukuk, özel mülkiyet ile birlikte doğmuş ve birlikte gelişmiş; birlikte gelişmektedir. Hukuk mülkiyet biçimindeki değişikliklere duyarlı bir gelişim gösterecektir. Bir mülkiyet biçiminin kendi içinde derinleşmesi, gelişmesi veya yeni bir biçime dönüşmesi hukukta da benzer sonuçlar doğuracaktır. Nitckim Alman Ideolojisinde (1845) de bu özellik saptanmaktadır: "Sanayi ve ticaretteki gelişimin yeni mübadele biçimleri yarattı̌̆ı her durumda, hukuk bunlan, düzenli olarak, mülkiyetin kazantlma tarzlarma yerleştirmek zorunda kal(ır) (MARX/ENGELS, 1992: 109)."

Bu sonuçlar karşısında şu soru ortaya çıkmaktadır. Mübadele/mülkiyet ilişkilèrine uygun biçimde gelişme özelliği hukukun kendine özgü bir tarihi/varlığ olmasını engeller mi? Alman Ideolojisi'nde (1845) üretim biçimi ile hukuk arasındaki ilişki kısaca anlatıldıktan sonra, "hukukun, dinden daha fazla bir kendine özqü tarihi olmadığı unutulmamalddr" ${ }^{\prime 2}$ saptaması yapılmaktadır. ${ }^{13}$

Marx/Engels'e göre hukuk salt bir yansıma değildir. Hukukun, sınırlı da olsa kendine özgü bir tarihi vardır. Burada sınırllıkla kastedilen, bir yctersizlik, zayıllık veya eksiklik anlamında değil, hukukun kaynağı ve işleviyle sıkı ilişkisinden kaynaklanan bir sınırlllıktır.

Hukukun kendine özgü tarihinin sınırl olmasının vurgulanma nedeni yine, dünyanın hukuksal bakış açısıyla kavranamayacağını belirtmektir. Nitekim bu kısa cümle, hukukun üretim biçimlcrinin gelişiminde oynadığı role ve özellikle modern sanayi ve ticaretin gelişimindeki etkisine ilişkin bir paragraflık bir açıklamanın sonunda yer almaktadır.

12 "Nicht zu vergessen, dass Recht ebensowenig eine eigene Geschichte hat wie die Religion. (Unutmamak gerekir ki, hukuk da tipkı din gibi stnırl bir kendine özgü tarihe sahiptir.)"

"It must not be forgotten that law has just as little an independent history as religion."

"N'oublions pas que le droit n'a pas davantage que la religion une histoire qui lui soit propre."

13 Alman Ideolojisinin (1845) tamamlanmamış "[12] Toplumsal Bilinç Biçimleri" başlıklı bölümünde, şöyle bir not yer almaktadır. "Siyasetin, hukukun, bilimin, vb., sanatın, dinin ob. Tarihi yoktur." 
Yukarıda, hukukun kaynağına ve üretim ilişkilerini "ifade etme" işlevine ilişkin olarak Marx ve Engels'ten aktardığımız değerlendirmeler, bu sorunun yanıtına ilişkin veriler de içermektedir.

Hukukun geleceği, Marksizmin devletin geleceğine ilişkin tezine bağlıdır. Engels Anti-Duhring'te (1878) devletin sönümlenmesinden söz etmektedir: "Iş̧̧i sinıfi, devlet iktidarın ele geçirir ve ilk elde üretim araçların devlet mülkiyetine dönüştürür. ... Devlet in gerçekten tüm toplumun temsilcisi olarak göründüğü ilk eylem, üretim araçlarına toplum adına elkonmast, aynı zamanda onun devlete özgü son eylemidir de. Devlet erkliliğinin toplumsal ilişkilere karışması, bir alandan sonra bir başkasında gereksiz duruma gelir ve sonra kendiliğinden uykuya dalar. Insanlarn yönetiminin yerini, şeylerin ve üretim sürecinin yönetimini alır. Devlet, ortadan kaldırlmaz, devlet sönümlenir (ENGELS, 1995: 400)." Devletin nasil ortadan kalkacağı Marksizmin önemli kuramsal ve siyasal tartı̧̧malanından birisidir. Burada devlet için söylenebilecekler, Engels'in nitelemesini kullanursak, "sözcügün hukuksal anlamında hukuk" için de geçerlidir.

Engels'in, Ailenin Özel Mülkiyetin ve Devlet in Kökeni'nde (1884), kullandığ "sözcüğün hukuksal anlamında hukuk" kavramını kullanarak denebilir ki, devletin sönümlenmesiyle, sözcüğün hukuksal anlamindaki hukuk da sönümlenecektir. Bu saptamalardan çıkarabileceğimiz tck ipucu, eğcr sözkonusu olacaksa yeni kuralsal sistemin arkasında örgütlü devlet gücünün bulunmayacağıdır. Kuralların kimin tarafından yazılacağı, kimin tarafından yaptırıma bağlanacağı, hatta yaptırım kavramının hâlâ geçerli olup olmayacağı, kuralların kimin tarafından uygulanıp, uyuşmazlıkların kimin tarafından çözüleceği gibi konular, görebildiğimiz kadarıyla, Marx ve Engels'in yazılarında işlenmemiştir.

\section{Siyasal Programda Hukuk}

Marx ve Engels'in hukuk konusundaki temel sorunu hukuksal dünya anlayışını veya başka bir ifadeyle hukuksal ideolojinin eleştirisi olmuştur. Dünyanın algılanışında hukukun ideolojik bir işlev gördüğü, bu bakış açısından kalkılarak tahlil yapılamayacağı ve siyasi program oluşturulamayacağı özellikle Gotha Programinin Eleştirisi'nde (1875) vurgulanmıştır.

Alman İşçi Partisi programında yer alan "kolektif emeğin, ürünlerin adil bölü̧̧ümü ilkesi çerçevesinde düzenlenmesi" gercktiğine ilişkin 3. maddesini eleştiren Marx, "adil bölüşüm nedir?" diye sormakta ve adalet kavramıyla, yani "hukuksal düşüncelerle iktisadi ilişkilerin düzenlenemeyeceğini, hukukun iktisadi ilişkilerden doğduğunu" vurgulamaktadır. Buna göre, varolan bölüşümün, burjuvazi tarafından adil olarak nitelenmesi mümkündür, zira varolan üretim biçiminde tek "adil bölüşüm" de budur.

Adalet gibi hukuksal bir kavramla, sosyalist bir partinin "temel" toplumsal değişiklik talebini ifade etmeye çalışması, Marx tarafından sert 
biçimde eleştirilmektedir. Marx, bu program hükmüyle Parti'ye bir dönem için anlamlı olan ama artık kullanşsız bos sözlere dönüşen dogmaları sokma, zorlukla yerleştirilen gerçekçi anlayışı, hukuksal ideolojinin saçma sözleriyle bozma girişiminde bulunulduğunu belirtmektedir (MARX, 1875: § I).

Marx'ın varolan üretim bölüşüm ilişkilerini, varolan üretim biçimi için "tek adil bölüşüm" olarak tanımlaması şaşırtıc görünebilir. Engels'e göre Marx, tarihsel üretim biçimine uygun, tarihsel meşruluklan tanımaktadır: "Marx'in teorik çalışmalarında, her zaman yalnızca belirli bir toplumun ekonomik koşullarını yansitmakla kalan hukuk, salt ikinci derecede, arka planda gözönüne alını. Buna karşılık, ön planda, belirli dönemler için, belirli durumlara ve belirli mülk edinme biçimlerine özgü bulunan ... 'tarihsel haklliklar', 'tarihsel meşruluklar' gözönünde tutulur. ... Emek ürünlerinin başkalarn tarafindan sahiplenilmesinin ve emeğin sömürülmesinin geçici bir süre için tarihsel meşruluğunu da kabul etmiş olur. Ne var ki Marx, aynı zamanda, bu tarihsel hakltlığın günümüzde ortadan kalktı̆̆ınt kanttlamakla kalmayıp, sömürünün şu veya bu biçimde süregelmesinin artık toplumsal gelişmeyi destekleyecek yerde bu gelişmeyi günbegün daha fazla kösteklediğini ve gitgide daha fazla çatı̧̧malara sürüklediğini de kanttlar (MARX/ENGELS, 1977: 175)."

Hukuksal dünya anlayışının yanlışlığı, siyasal mücadelede hukukun tamamen bir kenara atılmasını da gerektirmemektedir. Dünyanın hukuksal kavramlaştırılmasınun yanlışlı̆̆ıa ilişkin sert eleştirilere karşın, Marksizm, siyasal mücadelede hukukun rolünü de tanımaktadır.

Engels ve Kautsky, yukarıda aktardığımı, "Hukukçular Sosyalizmi" başlıklı yazılarında, hukuksal dünya anlayışına ilişkin eleştirilerinden sonra, hukukun sınıfsal/siyasal mücadeledeki öncmini de vurgulamışlardır. "Bu sözlerimle sosyalistlerin belirli hukuki taleplerde bulunmaktan feragat edeceklerini ileri sürmek istemiyorum. Aktif bir sosyalist parti, bütün siyasal partiler gibi bu tip hukuki talepler varolmaksizın düşünülemez. Bir sinifin ortak yararlanndan çıkan talepler, ancak bu stnifin siyasal iktidan fethetmesi ve taleplerine yasalar kaliğında genel bir yürürlülük sağlaması sayesinde gerçekleştirilebilirler. Mücadele eden her sintf programinda taleplerini hukuki talepler kilığında formüle etmek zorundadır. [Ancak] temel olarak fiili ilişkiler alınır. Yoksa hiçbir sosyalist partinin aklına, programıyla yepyeni bir hukuk felsefesi yaratmak gelmez (MARX/ENGELS, 1977: 179)."

\section{SONUÇ}

Hukuk alanı, Marx tarafından terk edildiği zamandan beri henüz Marksistlerin ilgisine mazhar olamamıştır. Sovyet Devrimi sonrası, Pasukanis'in hukuk genel teorisi çalı̧̧ma girişiminin etkisi ise, bastrrılmasındaki şiddetten olsa gerck, çok kısa ömürlü olmuştur. Hukuk düşüncesinin, varolan kapitalist hukukun temel kavram, ilke ve kategorilcrinin, yorum yöntemlerinin, genel olarak metodolojisinin Marksist bir eleştirisi henüz gerçekleştirilmemiştir. 
Marksistlerin önünde duran böylesi bir görevin bir adım ötesine geçerck, yeni veya düzeltilmiş kavram, ilke, kategori ve metodoloji ile yeni bir hukuk inşa etmenin mümkün olup olamayacağı ayrı bir sorudur. Ancak devrim sonrası durumlar için anlamlı olabilecek bu soru, Pasukanis tarafından tartı̧̧ılmış ve olumsuz yanitlanmıştr.

Marksizm hukukla ancak eleştiri ilişkisi kurabilir. Marksizm ancak eleştirel bir işlev görecektir. Yeni bir hukuk yaratılamasa da yeni bir hukuksal inceleme metodolojisi geliştirmek mümkündür. Ancak burjuva hukuk sisteminin, Marksist yöntemle incelenmesinin, eleştirel hukuk yaklaşımı geliştirilmesinin önündeki en büyük engel, gerçckten zorlu olan bu uğraşın, tatminkar somut uygulamalı sonuçlar üretme ihtimalinin zayıf olmasıdır. Hukuk uygulayıcıları için bu çok açıtır. Bu nedenle, Marksizmle hukuk alanını buluşturmak işi, teorisyenlerin ayrıcalık alanında kalma riskini taşımaktadır. Ayrıca, Marksist yaklaşımı benimseyen az sayıdaki meslekten hukukçunun bu yaklaşımından, meslek alanlarına hiçbir ışık sızmaması da önemli bir tatminsizlik kaynağıdır (hukukçu Marksistin, marksist hukukçu olamaması). Kanumca bu iki yönlü engeli aşacak; eleştirisinin somut uygulamalı sonuçları olmayan, köklü eleştirisine rağmen yine de eleştirdiği kavramların uygulanmasına katlanmak ve aracılık etmek zorunda olan hukukçunun, düşünsel tatminsizliğinin yaratacağı hayal kırıklığının önüne geçecek, enazından bunu tahammül edilebilir kılacak tek yol, bizzat eleştirinin de öncmli bir devrimci pratik olduğunun unutulmamasıdır.

\section{Kaynakça}

ENGELS, Friedrich (1990), Ailenin Ozel Mälkiyetin ve Devletin Kökeni (Ankara: Sol Yayınları, 9. Baskı) (Cev.: Kenan Somer).

ENGELS, Friedrich (1886), Ludwig Feuerbach and the end of Clarissical German Philosophy. http:www.marxists.org/marx/works/1886/ludwig-feuerbach/index.htm, 8.7.2002.

ENGELS, Friedrich (1992), Ludwig Feuerbach Klasik Alman Felsefesinin Sonu (Ankara: Sol Yayınları, 3.Baskı) (Cev.: Sevim Belli).

ENGELS, Friedrich (1890), Letter from Engels to Conrad Schmidt, http://www.marxists.org/archive/marx/ letter/engels/90-10-27.htm, 8.7.2002.

ENGELS, Friedrich (1995), Anli-Dühring. Bay Eugen Dühring Bilimi Allüst Ediyor (Ankara: Sol Yayınları, 3.Baskı) (Cev.: Kenan Somer).

ENGELS, Friedrich/KAUTSKY, Karl (1995), "Hukukçular Sosyalizm' (1887), "Din Ozerine (Ankara: Sol Yayınlan, 2.Baskı, (Cev.: Kaya Güvenç).

MARX, Karl (1837), Letter from Karl to his Father in Trier, http://www.marxists.org/archive/marx/work/1837pre/letters/37-1 1-10.htm, 8.7.2002.

MARX, Karl (1849), The Trial of the Rhenish District Commillee of Democrats http://www.marxists.org/archive/marx/works/1849/02/07.htm, 8.7.2002. 
MARX, Karl (1851), Le 18 brumaire de l. Bonaparte, http://www.marxists.org/francais/marx/works/1851/12/ $\mathrm{km} 18650124 . \mathrm{htm}, 8.7 .2002$ l.

MARX, Karl (1865), Leture à J.B. Schweitzer, http://www.marxists.org/francais/marx/works/1865/01/ $\mathrm{km} 18650124 . \mathrm{htm}, 8.7 .2002$.

MARX, Karl (1875), Gloses marginales au programme du Parti Ouvrier allemand, http://www.marxists.org/ francais/marx/works/1875/05/18750500.htm, 8.7.2002.

MARX, Karl (1976), 1844 Elyazmaları, Ekonomi Politik ve Felsefe (Ankara: Sol Yayınları) (Gev.: Kenan Somer).

MARX, Karl (1986), 1844 Felsefe Yazulan (Ankara: V Yayınları) (Cev.: Murat Belge).

MARX, Karl (1990), Louis Bonaparte'un 18 Brumaire'i (Ankara: Sol Yayınlan, 2.Baskı) (Cev.: Sevim Belli).

MARX, Karl (1993). Ekonomi Politiğin Eleştirisine Katkı (Ankara: Sol Yayınları) (Cev.: Sevim Belli).

MARX, Karl (1997). Hegel'in Hukuk Felselesinin Eleşlirisi (Ankara: Sol Yayınları) (Cev.: Kenan Somer).

MARX, Karl (1998), Philosphie (Paris: Folio/Gallimard).

MARX, Karl/ENGELS, Friedrich (1977). Devlet ve Hukuk Ozerine (Istanbul: May Yayınları) (Cev./der.: Rona Serozan).

MARX, Karl/ENGELS. Friedrich (1992), Alman /deolojisi (Ankara: Sol Yayınları, 3.Baskı, (Cev.: Sevim Belli).

MARX, Karl/ENGELS, Friedrich (1995), Seçme Yazışmalar I (1844J869) (Ankara: Sol Yayınları) (Cev.: Yurdakul Fincanc1).

MARX, Karl/ENGELS, Friedrich (1996), Seçme Yazışmalar II (1870-1895) (Ankara: Sol Yayınları) (Cev.: Yurdakul Fincancı).

PASUKANIS, E. (1970), La théorie général du droit et le Marxisme (Paris: EDI).

STMA I, Sosyalizm ve Toplumsal Mücadeleler Ansiklopedisi (I) (lletişim Yayınları.

STOYANOVIC, K. (1965), Marxisme et Droit (Paris: LGDJ).

The Marxist-Leninist Research Bureau, Marxism and Law (The Struggle Over Jurisprudence in the Soviet Union), http//website.lineone.net/ comleague/intercom/law.html, 8.2.2002 